\title{
Epigenomic and metabolic responses of hypothalamic POMC neurons to gestational nicotine exposure in adult offspring
}

\author{
Jose P. Silva ${ }^{1 *}$, Guerline Lambert ${ }^{1}$, Derek van Booven ${ }^{2}$ and Claes Wahlestedt ${ }^{1}$
}

\begin{abstract}
Background: Epidemiological and animal studies have reported that prenatal nicotine exposure (PNE) leads to obesity and type-2 diabetes in offspring. Central leptin-melanocortin signaling via hypothalamic arcuate proopiomelanocortin (POMC) neurons is crucial for the regulation of energy and glucose balance. Furthermore, hypothalamic POMC neurons were recently found to mediate the anorectic effects of nicotine through activation of acetylcholine receptors. Here, we hypothesized that PNE impairs leptin-melanocortinergic regulation of energy balance in first-generation offspring by altering expression of long non-coding RNAs (IncRNAs) putatively regulating development and/or function of hypothalamic POMC neurons.
\end{abstract}

Methods: C57BL/6J females were exposed ad libitum to nicotine through drinking water and crossed with C57BL/6J males. Nicotine exposure was sustained during pregnancy and discontinued at parturition. Offspring development was monitored from birth into adulthood. From the age of 8 weeks, central leptin-melanocortin signaling, diabetes, and obesity susceptibility were assessed in male offspring fed a low-fat or high-fat diet for 16 weeks. Nicotine-exposed and non-exposed C57BL/6J females were also crossed with C57BL/6J males expressing the enhanced green fluorescent protein specifically in POMC neurons. Transgenic male offspring were subjected to laser microdissections and RNA sequencing (RNA-seq) analysis of POMC neurons for determination of nicotineinduced gene expression changes and regulatory IncRNA/protein-coding gene interactions.

Results: Contrary to expectation based on previous studies, PNE did not impair but rather enhanced leptinmelanocortinergic regulation of energy and glucose balance via POMC neurons in offspring. RNA-seq of laser microdissected POMC neurons revealed only one consistent change, upregulation of Gm15851, a IncRNA of yet unidentified function, in nicotine-exposed offspring. RNA-seq further suggested 82 cis-regulatory IncRNA/proteincoding gene interactions, 19 of which involved coding genes regulating neural development and/or function, and revealed expression of several previously unidentified metabolic, neuroendocrine, and neurodevelopment pathways in POMC neurons.

Conclusions: PNE does not result in obesity and type 2 diabetes but instead enhances leptin-melanocortinergic feeding and body weight regulation via POMC neurons in adult offspring. PNE leads to selective upregulation of Gm15851, a IncRNA, in adult offspring POMC neurons. POMC neurons express several IncRNAs and pathways possibly regulating POMC neuronal development and/or function.

Keywords: POMC neurons, Leptin-melanocortin signaling, Gestational nicotine exposure, Obesity, Type 2 diabetes, Epigenomics, Transcriptomics, IncRNA, Gm15851

(Continued on next page)

\footnotetext{
* Correspondence: jossil68@gmail.com

${ }^{1}$ Department of Psychiatry and Behavioral Sciences and Center for

Therapeutic Innovation, Miller School of Medicine, University of Miami,

Miami, FL 33136, USA

Full list of author information is available at the end of the article
} 
(Continued from previous page)

Abbreviations: AgRP, Agouti-related protein; CRF, Cortocotropin-releasing factor; EGF, Epidermal growth factor; FDR, False discovery rate; FGF, Fibroblast growth factor; GnRH, Gonadotropin-releasing hormone; GT, Glucose tolerance test; HFD, High-fat diet; ip, Intraperitoneal; ITT, Insulin tolerance test; Kb, Kilobases; lincRNA, long intergenic non-coding RNA; IncRNA, long non-coding RNA; MC3/4-Rs, Melanocortin 3/4 receptors; MTII, Melanotan II; ncRNA, non-coding RNA; NMR, Nuclear magnetic resonance; NPY, Neuropeptide Y; PBS, Phosphate buffered saline; PD, Postnatal day; PDGF, Platelet-derived growth factor; PNE, Prenatal nicotine exposure; POMC, Proopiomelanocortin; PVN, Periventricular nucleus; RM ANOVA, Repeated measures ANOVA; RNA-seq, RNA sequencing; RRID, Research resource identifier; STAT3, Signal transducer and activator of transcription 3; STD, Standard (low-fat) diet; TGF- $\beta$, Transforming growth factor $\beta$; TRH, Thyrotropin-releasing hormone; VMH, Ventromedial hypothalamic nucleus; a-MSH, a-melanocytestimulating hormone

\section{Background}

The adipocyte-secreted hormone leptin has critical anorectic and body weight-lowering actions that are mediated by the central melanocortin system $[1,2]$. The melanocortin system consists of first order signaling neurons in the hypothalamic arcuate nucleus comprising neuropeptide Y (NPY) and Agouti-related protein (AgRP) co-expressing neurons and of proopiomelanocortin (POMC)-expressing neurons. These first order signaling neurons project to second order signaling neurons expressing melanocortin 3 and 4 receptors (MC3/ 4-Rs) located in several hypothalamic and extrahypothalamic areas, where they exert anorectic actions, including the periventricular nucleus (PVN), a satiety center, and the lateral hypothalamic area (LHA), a feeding center. POMC is a precursor polypeptide for $\alpha$-melanocytestimulating hormone $(\alpha-\mathrm{MSH}) . \alpha-\mathrm{MSH}$ acts as an agonist to MC3/4-Rs of second order signaling neurons in the PVN to inhibit food intake and increase energy expenditure. AgRP is an antagonist of $\alpha-\mathrm{MSH}$ at $\mathrm{MC} 3 / 4-$ Rs and potent activator of food intake and body weight gain. Leptin regulates transcription of the genes encoding POMC and AgRP. Leptin binds to leptin receptors expressed in POMC and NPY/AgRP neurons. This triggers phosphorylation and activation of Janus kinase 2 (JAK2), which in turn phosphorylates signal transducer and activator of transcription 3 (P-STAT3). P-STAT3 homodimerizes and translocates to the nucleus to promote transcription of the POMC gene and inhibit transcription of the AgRP gene [3]. Leptin also stimulates release of $\alpha$ $\mathrm{MSH}$ from POMC neurons [4] and inhibits release of AgRP from NPY/AgRP neurons [5]. Independently of decreasing food consumption and body weight, leptin signaling via hypothalamic POMC neurons potently decreases glycemia and increases locomotor activity, thereby preventing hyperglycemia and normalizing physical activity of morbidly obese, severely diabetic, and hypoactive, leptinreceptor deficient Lepr ${ }^{\mathrm{db} / \mathrm{db}}$ mice [6].

Mutations of the leptin, leptin receptor, POMC, and MC4- $R$ genes lead to severe obesity in rodents and in humans, underscoring the importance of central leptinmelanocortin signaling for the regulation of energy balance [7-9]. Furthermore, common human obesity is frequently associated with leptin resistance characterized by an inability of leptin to decrease body weight.

Nicotine has anorectic effects. One underlying mechanism is the activation of hypothalamic POMC neurons by nicotinic $\alpha 3 \beta 4$ acetylcholine receptors and the subsequent activation of MC4-R expressing target neurons in the PVN [10]. The metabolic consequences of gestational nicotine exposure in first-generation offspring have been investigated in human epidemiological studies [11-14] and rodent models [15-18]. These studies concluded that gestational nicotine exposure increases the risk for obesity and type 2 diabetes in offspring. Furthermore, it was reported that in utero or early postnatal nicotine exposure upregulates POMC mRNA in neonate rhesus macaque $[19,20]$. These observations led us to hypothesize that gestational nicotine exposure impacts leptin-melanocortinergic regulation of energy balance in first-generation offspring.

More than $70 \%$ of the mammalian genome is transcribed as non-coding RNAs (ncRNAs) of various sizes ranging from 20 nucleotides to over $100 \mathrm{~kb}$ [21, 22]. NcRNAs are subdivided into short and long ncRNAs (lncRNAs), which are shorter and longer than 200 nucleotides, respectively [23], as well as processed transcripts, which do not contain an open reading frame, do not contain retained introns, and cannot be placed in the short and long ncRNA group. Similar to protein-coding mRNAs, lncRNAs can be spliced, polyadenylated, and capped [23]. LncRNAs are subdivided into: (1) antisense RNAs, which are transcribed from the opposite DNA strand of a protein-coding gene overlapping its intronic and exonic sequences; (2) long intergenic non-coding RNAs (lincRNA) transcribed from intergenic DNA regions; (3) sense-intronic RNAs transcribed from introns of a protein-coding gene on the same DNA strand with no overlap of exonic sequence; (4) sense-overlapping RNAs containing a protein-coding gene in one of its 
introns on the same DNA strand with no overlap of exonic sequence; and (5) 3'-overlapping ncRNAs, which are transcribed from the 3 '-untranslated region of a larger gene. LncRNAs are predominantly localized in the nucleus at usually much lower expression levels than mRNAs.

While lncRNAs were initially believed to represent transcriptional noise, studies in recent years have revealed developmental-, tissue- and cell-type-specific expression of lncRNAs [24, 25] and regulatory roles in important biological processes such as X-chromosome inactivation in females, silencing of tumor suppressor genes, mediation of DNA damage and cellular stress responses, gene imprinting, heterochromatin spreading across DNA insulator sequences, regulation of stem cell pluripotency, cell fate specification, and neural development [26-30]. However, although many different biological functions have been assigned to lncRNAs, most lncRNAs lack functional annotations. LncRNA genes show poorer sequence conservation than protein-coding genes although well-conserved lncRNAs with biologically important functions exist [31]. The number of lncRNA genes has dramatically increased in late evolution and appears to scale with genome size. Meanwhile, the number of protein-coding genes has not markedly increased during late evolution. Therefore, one emergent hypothesis is that the increase in lncRNA genes contributes to regulatory and organismal complexity [32]. LncRNAs can regulate expression of flanking or overlapping coding genes ("cis-regulation") or far distant coding genes located on the same or another chromosome ("trans-regulation") in a positive (concordant) or negative (discordant) manner [25, 33, 34]. LncRNA-guided gene regulation involves epigenetic, transcriptional, and post-transcriptional mechanisms. LncRNAs are thought to provide scaffolds for histone methyltransferases, histone acetylases, and DNA methyltransferases [26, 27], and can regulate splicing, editing, or degradation of protein-coding RNAs [26].

Here we interrogated whether PNE alters expression of IncRNAs with putative roles in hypothalamic POMC neuronal development/function and leptinmelanocortinergic regulation of energy balance in first-generation offspring in a mouse model of human maternal nicotine exposure from adolescence until parturition. We found that PNE does not impair but rather enhances leptin-melanocortinergic regulation of energy balance in first-generation offspring and selectively upregulates expression of Gm15851, a lncRNA of yet unidentified function, in hypothalamic POMC neurons. Furthermore, we report expression of several signaling pathways and lncRNAs that might regulate development and function of hypothalamic POMC neurons.

\section{Methods}

\section{Animals}

Animals used in the study were from the C57BL/6J mouse strain (RRID:IMSR_JAX:000664, Jackson Laboratories, Bar Harbor, ME, USA) or transgenic mice expressing the enhanced green fluorescent protein (EGFP) in hypothalamic POMC neurons (C57BL/6J- $\mathrm{Tg}$ (PomcEGFP)1Low/J, RRID:IMSR_JAX:009593, Jackson Laboratories, Bar Harbor, ME, USA). Metabolic, hormonal, hypothalamic gene expression and leptin-signaling studies were conducted in C57BL/6J male offspring. RNA sequencing (RNA-seq) studies of laser microdissected POMC neurons were conducted in POMC-EGFP transgenic male offspring. POMC-EGFP transgenic offspring were tail biopsied at postnatal day 17 and genotyped using established PCR protocols provided by the Jackson Laboratories. Offspring were weaned at postnatal day 21 and kept in groups of 3-4 mice per cage. Male offspring were singly housed with environmental enrichment from the age of 8 weeks onwards until the end of the study. All mice were housed in a pathogen-free barrier animal facility and kept in a temperature-controlled (22 \pm $0.5{ }^{\circ} \mathrm{C}$ ) and humidity-controlled (50\%) animal room on a $12 \mathrm{~h} \mathrm{light/dark}$ schedule with light on at 07:00 and free access to food and water.

\section{Prenatal nicotine exposure}

Six-week-old females were treated for 4 weeks ad libitum with drinking water containing $200 \mu \mathrm{g} / \mathrm{mL}$ nicotine hydrogen tartrate sweetened with $2 \%$ saccharin $(w / v)$, pH 7.4 [35]. Controls were administered pH-matched drinking water containing the equivalent amount of tartaric acid and $2 \%$ saccharin $(\mathrm{w} / \mathrm{v})$. The inclusion of saccharin was required because nicotine in the drinking water causes taste-aversion [36, 37] and reduces maternal fluid intake [35]. Drinking solutions were changed twice a week. At the age of 10 weeks, females were mated to unexposed males. Nicotine administration continued throughout mating and pregnancy and was discontinued at parturition. Mothers were allowed only one pregnancy.

\section{Determination of plasma cotinine}

Plasma cotinine levels were determined using a Cotinine (Mouse/Rat) enzyme linked immunosorbent assay kit (Abnova, Walnut, CA, USA) following the manufacturer's directions. All samples were assayed in duplicates. The intra-assay coefficient of variation $(\mathrm{CV})$ of the cotinine ELISA measurements was $3.9 \%$.

\section{Diets}

All animals were fed a standard (low-fat) diet (STD) with a metabolizable energy density of $3.1 \mathrm{kcal} / \mathrm{g}$ derived from $28.7 \% \mathrm{kcal}$ protein, $58.53 \% \mathrm{kcal}$ carbohydrates, and 
$12.73 \% \mathrm{kcal}$ fat (5010, LabDiet, St Louis, MO, USA). A subset of male offspring was subjected to a high-fat diet (HFD) with a metabolizable energy density of $4.7 \mathrm{kcal} / \mathrm{g}$ derived from $17 \% \mathrm{kcal}$ protein, $43 \% \mathrm{kcal}$ carbohydrates, and $41 \% \mathrm{kcal}$ fat, containing $0.21 \%(\mathrm{w} / \mathrm{w})$ Cholesterol (Western Diet, Research Diets, Inc., New Brunswick, NJ, USA) starting from the age of 8 weeks.

\section{Determination of energy balance}

Body composition (body fat content, lean mass, and body fluid) was determined by nuclear magnetic resonance (minispec TD-NMR Analyzer, Bruker Optics, Inc., Billerica, MA, USA). Food consumption of singly housed animals was measured twice a week. Fresh food pellets were provided twice a week to avoid temperaturedependent spoilage. Any residual bits of food in the bedding were included in the measurements. A comprehensive laboratory animal monitoring system (Columbus Instruments, Columbus, OH, USA) determined oxygen consumption, carbon dioxide production, heat production, locomotor activity, and food intake simultaneously in individual animals. Measurements were taken in metabolic cages placed in a temperature-controlled enclosure set at $23.5{ }^{\circ} \mathrm{C}$. Mice were acclimated to the metabolic cages for $72 \mathrm{~h}$ prior to measurements for an additional $72 \mathrm{~h}$.

\section{Determination of glucose balance}

Blood glucose measurements were carried out with a OneTouch glucometer (LifeScan, Inc.). Blood glucose and insulin concentrations were determined by tail venipuncture and submandibular bleeding, respectively, between 09:00 and 10:00 following 14 h of fasting. Insulin was measured by enzyme linked immunosorbent assay (Ultra Sensitive Mouse Insulin ELISA Kit, Crystal Chem, Inc., Chicago, IL, USA). All samples were assayed in duplicates. The intra-assay CV of the insulin ELISA measurements was $9.9 \%$. Glucose tolerance tests (GTTs) were conducted in $14 \mathrm{~h}$ fasted mice by injecting i.p. glucose $1 \mathrm{~g} / \mathrm{kg}$ body weight. Insulin tolerance tests (ITTs) were conducted in $6 \mathrm{~h}$ fasted mice by injecting i.p. Insulin (Humulin R, Eli Lilly, Indianapolis, IN, USA) $0.5 \mathrm{IU} / \mathrm{kg}$ body weight. Blood glucose concentrations for the GTT and ITT were measured from the tail tip. Calculating the area under the curve (AUC) of glucose concentration-time point graphs using Prism 5 (RRID:SCR_002798, GraphPad Software, La Jolla, CA, USA) quantitatively assessed glucose and insulin tolerance.

\section{Determination of plasma lipids}

All plasma lipids were determined using VITROS $^{\circ}$ Chemistry Products and analyzer (Ortho-Clinical Diagnostics, Inc., Rochester, NY, USA). Total cholesterol
(Tot Chol) was measured by the VITROS CHOL Slide method. High-density lipoprotein cholesterol (HDL-C) was determined by the VITROS direct HDL-C (dHDL) slide assay. Triglycerides were measured by the VITROS TRIG Slide method. Low density lipoprotein cholesterol (LDL-C) and Very low density lipoprotein cholesterol (VLDL-C) concentrations were calculated as follows: VLDL-C $=\mathrm{TG} / 5$; $\mathrm{LDL}-\mathrm{C}=\mathrm{T}$ t $\mathrm{Chol}-\mathrm{HDL}-$ C - VLDL-C.

\section{Refeeding experiments and determination of Leptin and MTII sensitivity}

Refeeding experiments were conducted as described previously [38]. Mice were fasted overnight for $12 \mathrm{~h}$ and then injected i.p. leptin $5 \mathrm{mg} / \mathrm{kg}$ (A.F. Parlow National Hormone and Peptide Program, Torrance, CA, USA), Melanotan II (MTII) $5 \mathrm{mg} / \mathrm{kg}$ (Tocris, Ellisville, MO, USA), or the equivalent volume of vehicle (phosphate buffered saline (PBS)). Body weight was determined prior to injection, as well as $1 \mathrm{~h}, 2 \mathrm{~h}, 4 \mathrm{~h}, 8 \mathrm{~h}$, and $24 \mathrm{~h}$ post injection. A known amount of food was added to each cage immediately after injection and food intake was measured $1 \mathrm{~h}, 2 \mathrm{~h}, 4 \mathrm{~h}, 8 \mathrm{~h}$, and $24 \mathrm{~h}$ post injection. Mice had unlimited access to water during the entire experiment. Plasma leptin concentrations were determined by ELISA (Mouse Leptin ELISA Kit, Crystal Chem, Inc., Chicago, IL, USA). All samples were assayed in duplicates. The intra-assay CV for the leptin ELISA measurements was $5.1 \%$.

\section{Immunofluorescence detection and quantification of leptin-induced nuclear STAT3 phosphorylation}

Mice were fasted overnight for $14 \mathrm{~h}$ and injected i.p. leptin $5 \mathrm{mg} / \mathrm{kg}(n=3)$ or the equivalent volume of vehicle (PBS) $(n=2-3)$. Thirty minutes post injection, animals were perfused with $10 \%$ formalin under general anesthesia. Brains were post-fixed in $10 \%$ formalin for $24 \mathrm{~h}$ at $4{ }^{\circ} \mathrm{C}$ and paraffine-embedded. Coronal sections were cut at $6 \mu \mathrm{m}$, deparaffinized, and rehydrated through sequential washes in Xylene, $95 \%$ ethanol, $70 \%$ ethanol, and water. Sections were permeabilized with PBS/0.3 \% Triton X-100 for 10 min and blocked with 5 \% normal goat serum in PBS/0.3 \% Triton X-100 for $1 \mathrm{~h}$ at room temperature. Sections were incubated overnight at $4{ }^{\circ} \mathrm{C}$ with mouse monoclonal Phospho-STAT3 (Tyr 705) antibody (Cell Signaling Technology, Danvers, MA, USA; Cat\# 4113S, RRID: AB_2198588) diluted 1:50 and rabbit anti-POMC antibody (Phoenix Pharmaceuticals, Inc., Burlingame, CA, USA; Cat\# H-029-30, RRID: AB_2307442) diluted 1:300 in $2 \%$ goat serum/PBS/0.3 \% Triton X-100. Another set of sections was incubated with rabbit monoclonal Phospho-STAT3 (Tyr 705) (D3A7) antibody (Cell Signaling Technology, Danvers, MA, USA; Cat\# 9145S, RRID:AB_561305) diluted 1:100 
in $1 \% \mathrm{BSA} / \mathrm{PBS} / 0.3 \%$ Triton $\mathrm{X}-100$. Sections were washed with PBS and then incubated with anti-rabbit IgG and anti-mouse IgG antibodies conjugated with the Alexa fluorochromes 488 and 555, respectively. After rinsing sections with PBS, Prolong ${ }^{\oplus}$ Gold Antifade Reagent (LifeTechnologies, Grand Island, NY, USA) was added and coverslips were mounted. Sections were analyzed on an inverted Leica Microsystems SP5 imaging system with an XYZ automated stage and AOBS wavelength controls for laser tuning. The system was equipped with a set of lasers providing the following laser lines: 405, 458, 476,488, 496, 514, 561, and $633 \mathrm{~nm}$. The system ran under the Leica Application Suite (LAS) AF 2.7.1 software. Images were acquired using a $20 \times$ dry lens with a numerical aperture of 0.7. Images were acquired from 3-4 matched (rostral-caudal) hypothalamic sections encompassing the bregma coordinates $-1.34 \mathrm{~mm}$ and $-2.06 \mathrm{~mm}$ [39]. P-STAT3 reactive POMC neurons were identified by co-localization of nuclear P-STAT3 and cytosolic POMC-polypeptide [38]. Differences in leptininduced P-STAT3 signaling were assessed by comparing average counts of P-STAT3-positive ARC neurons or PSTAT3-positive POMC neurons in brain sections of individual mice ( $n=3$ mice per group).

\section{Determination of hypothalamic POMC mRNA expression}

Total RNA was isolated from microdissected whole hypothalami using the RNeasy Mini kit (Qiagen). Total RNA (500 ng) was reverse transcribed (Superscript III first strand cDNA synthesis kit; Invitrogen, ThermoFisher Scientific). Real-time PCR reactions were carried out on an ABI 7900HT light cycler using the Taqman Universal Master Mix and validated gene-specific Taqman expression assays for proopiomelanocortin and $\beta$ actin (Applied Biosystems, ThermoFisher Scientific). POMC mRNA was normalized to $\beta$-actin mRNA by the $\Delta \Delta \mathrm{Ct}$ method.

\section{Laser micro-dissections and RNA extractions of hypothalamic POMC neurons}

Prenatally nicotine-exposed and non-exposed transgenic adult male mice expressing the enhanced green fluorescent protein in hypothalamic POMC neurons [40] were euthanized in week 10 of the STD by $\mathrm{CO}_{2}$ inhalation followed by cervical dislocation and decapitation. Brains were quickly removed, fresh-frozen in dry ice, and stored at $-80{ }^{\circ} \mathrm{C}$. Brains were sectioned on a cryostat Leica CM $3050 \mathrm{~S}$ at $15 \mu \mathrm{m}$. Sections were attached onto Director ${ }^{\bullet}$ slides (Expression Pathology, Inc., Rockville, MD, USA), dehydrated in acetone for $1 \mathrm{~min}$ at room temperature, and desiccated for $2 \mathrm{~min}$ in a closed petri-dish containing dessicant (Drierite). Slides were immediately placed upside-down on the stage of a laser microdissection microscope Leica AS LMD equipped with a HCX PL
Fluotar $20 \times / 0.4$ NA lens and a Hitachi HV-C20A camera. POMC-GFP neurons in the mediobasal hypothalamus were visualized by the green fluorescent appearance of their cell bodies, which were collected directly in $20 \mu \mathrm{L}$ lysis buffer of the RNAequous microextraction kit (Life Technologies, ThermoFisher Scientific). Collections from individual sections were not allowed to continue for more than $30 \mathrm{~min}$. Lysates were immediately frozen on dry ice and stored at $-80{ }^{\circ} \mathrm{C}$. Between 400 and 600 POMC neurons were isolated from the entire hypothalamus of each mouse brain. RNA was isolated following the directions provided in the RNAequous microextraction kit. RNA samples were run on an electropherogram (2100 Bioanalyzer, Agilent Technologies) for determination of RNA quality, concentration, and yield. Samples with RNA integrity numbers (RIN) above 6 were used for generation of RNA-seq libraries.

\section{RNA sequencing}

A range of 1-2 offspring coming from five different nicotine-exposed dams ( $n=6$ PNE offspring total) and 1-2 offspring coming from four different non-exposed dams ( $n=5$ control offspring total) were subjected to RNA-seq. Directional RNA-seq libraries were generated from a range of 200-400 pg total RNA using the Ovation Single Cell RNA-seq kit (NuGen, San Carlos, CA, USA) following the manufacturer's directions. All RNA-seq libraries were run on an electropherogram (2100 Bioanalyzer, Agilent Technologies) to confirm the expected fragment size distribution. Libraries were paired-end sequenced on Illumina's HiSeq2000 sequencer. Of all read-pairs, 90-95\% passed Illumina's quality filters. For subsequent alignments, the first eight nucleotides of the forward read were trimmed according to the manufacturer's directions for analysis of Ovation Single Cell RNA-seq libraries. Pass-filter read-pairs were aligned to the mouse reference mm10 genome using STAR [41]. Read-pairs aligning to the genome with more than two mismatches or aligning to more than one site of the genome were discarded from further analyses. The aligned read-pairs were run through HTSeq (RRID:SCR_005514) for transcript quantification against the GENCODE reference gtf file vM4 for the mouse mm10 genome [42]. After all features had been quantified the data was run through three differential expression calculators in edgeR (RRID:SCR_012802) [43], DESeq (RRID:SCR_000154) [44], and baySeq (RRID:SCR_012795) [45]. The intersection of the three methods was taken and transformed into a list of the final differentially expressed features. Differentially expressed features were determined by cutoff adjusted $p$ values of 0.05 across all three methods. For heatmap generation, the default parameters of the heatmap.2 function within the $\mathrm{R}$ package gplots $\mathrm{v} 2.16 .0$ 
(https://cran.r-project.org/web/packages/gplots/index. html) were used. Function and expression annotations for coding and non-coding genes were retrieved from the Protein ANalysis THrough Evolutionary Relationships (PANTHER) Classification System (RRID:SCR_004869) [46]. Expression differences of Gm15851 were confirmed by strand-specific qRT-PCR in the same RNA samples used for RNA-seq ( $n=6$ PNE offspring; $n=5$ control offspring). Following quantitation of RNA concentrations by the RNA 6000 pico assay on an Agilent 2100 Bioanalyzer (Agilent Technologies), 500 pg of total RNA was reverse transcribed using a strand-specific primer (sequence: TCCTGGATCTGCAGCACAATCG) annealing to the Gm15851 transcript and the superscript IV first strand synthesis system (ThermoFisher Scientific). Reaction conditions followed the manufacturer's directions. After cDNA synthesis, the RNA template was digested with RNAse H. Real-time PCR reactions were run in triplicate using a custom-built Taqman gene expression assay for Gm15851 (forward primer sequence: CCGGCACGTT GCTGATC; reverse primer sequence: CTCCTTCAAC ATCTCCAACTTGCT; Taqman reporter sequence: CCACCTGTCTCACAACAA) (ThermoFisher Scientific) on a QuantStudio 7 Flex real time PCR system (ThermoFisher Scientific). Ct values were determined with QuantStudio software (ThermoFisher Scientific). Dilutions of an expression plasmid containing the cDNA sequence of Gm15851 were assayed in parallel to generate a reference standard curve and quantitate the relative amounts of Gm15851 in each sample.

\section{Data analysis}

Study groups consisted of $n=7-9$ male offspring unless otherwise indicated. Male offspring were selected from $n=6$ nicotine-exposed and $n=7$ non-exposed litters. Male offspring in each study group originated from $n=$ 3-4 different dams. Statistical analyses were conducted with GraphPad Prism 5 (RRID:SCR_002798, GraphPad Software, La Jolla, CA, USA). Data were subjected to various normality tests (Kolmogorov-Smirnov, D'Agostino-Pearson Omnibus, and Shapiro-Wilk) prior to performing the following parametric or non-parametric statistical tests: two-tailed unpaired $t$ test, Welch's test for uneven variances, and Mann-Whitney test for twogroup comparisons; Fisher's exact test for contingency analyses of postnatal survival; two-way ANOVA for determination of the effect of PNE and diet on metabolic, hormonal, and gene expression parameters, and the combined effect of PNE and leptin/MTII on body weight gain and food intake in refeeding experiments; two-way repeated measures (RM) ANOVA for determination of the effect of nicotine on maternal fluid intake, food intake, and body weight before and during gestation and the effect of PNE on glucose and insulin tolerance;
Bonferroni post-tests following ANOVA for two-group comparisons. The $\alpha$-value was set at 0.05 for each statistical test. Data were expressed as mean \pm SEM.

\section{Results}

Prenatal nicotine exposure and early postnatal development of offspring used in the study

C57BL/6J females were exposed to nicotine ad libitum through drinking water containing nicotine hydrogen tartrate salt at a concentration of $200 \mu \mathrm{g} / \mathrm{mL}$. Controls received drinking water containing the equivalent amount of $\mathrm{pH}$-matched tartaric acid. Nicotine exposure started at the age of 6 weeks, continued throughout mating at the age of 10 weeks and gestation, and ended at parturition. Since nicotine causes taste aversion [36, 37], the drinking water of both, nicotine-exposed and nonexposed dams was sweetened with $2 \%(\mathrm{w} / \mathrm{v})$ saccharin [35]. Nicotine moderately reduced weekly fluid volume intake before and during gestation (Pre-Gestation: $\mathrm{F}_{1,12}=$ 5.41, $p=0.06$; Gestation: $\mathrm{F}_{1,36}=23.4, p=0.0001 ; \mathrm{RM}$ ANOVA) (Fig. 1a). The mean daily water intake of nicotine-exposed females $(\approx 2 \mathrm{~mL} / 10$ g body weight $/ 24 \mathrm{~h}$ at $6-8$ weeks of age) remained moderately above the mean values reported for wild-type mice of unspecified sex, strain, and age $(1.5 \mathrm{~mL} / 10 \mathrm{~g}$ body weight $/ 24 \mathrm{~h})$ and those reported for C57BL/6 females aged 7-9 weeks (1.64 mL/ $10 \mathrm{~g}$ body weight/24 h, Mouse Phenome Data Base, The Jackson Laboratory). Mean daily nicotine ingestion calculated based on fluid intake was $0.77 \pm 0.03 \mathrm{mg} /$ day $(n=4)$ before pregnancy and $0.92 \pm 0.03 \mathrm{mg} /$ day $(n=10)$ during pregnancy (Fig. 1b). Moreover, the plasma levels of cotinine, a metabolite of nicotine, and indicator of tobacco smoke exposure in humans [47] determined after 4 weeks of ad libitum nicotine intake were in the range of 137.4$385.1 \mathrm{ng} / \mathrm{mL}$ (mean value: $245 \pm 0.03 \mathrm{ng} / \mathrm{mL} ; n=6$ ) (Fig. 1c). These plasma cotinine values are within the range reported in humans who smoke 15-24 cigarettes/ day and $>25$ cigarettes/day and exhibit serum cotinine concentrations of $230-280 \mathrm{ng} / \mathrm{mL}$ and $260-300 \mathrm{ng} / \mathrm{mL}$, respectively [48]. Plasma cotinine was undetectable in age-matched non-exposed dams. Ad libitum nicotine ingestion had no significant impact on maternal food intake $\left(\mathrm{F}_{1,12}=3.04, p=0.13\right.$; RM ANOVA) (Fig. $1 \mathrm{~d}$ ) or maternal body weight $\left(\mathrm{F}_{1,44}=3.4, p=0.08\right.$; RM ANOVA) (Fig. 1e) as reported for the C57BL/6 mouse strain [35]. Dams were allowed only one pregnancy. Nicotine-exposed and nonexposed litters displayed no significant difference in mean litter size at postnatal day (PD) 1 (PNE: $6.7 \pm 0.37$; control: $6.1 \pm 0.3 ; n=10$ litters/group; $\mathrm{t}_{18}=1.24, p=0.23 ; t$ test). Postnatal survival of PNE offspring tended to be more compromised than that of control offspring (62.7\% versus $73.8 \%$ ) by PD21 but contingency analysis of alive and dead PD21 offspring revealed no significant differences between groups ( $p=0.19$ by two-sided Fisher's exact test) 

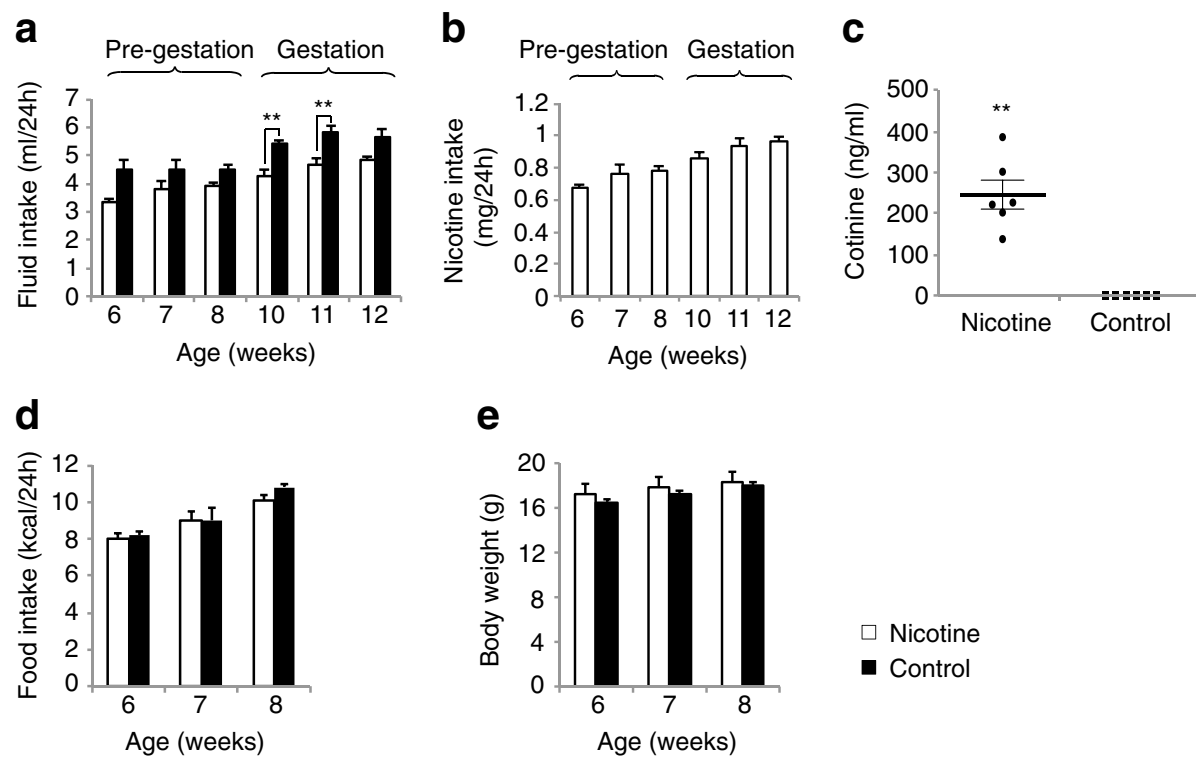

Fig. 1 Ad libitum nicotine intake led to high plasma cotinine levels, moderately reduced fluid intake, and did not alter body weight or food consumption of dams. a Twenty-four-hour fluid intake was determined in group-housed females ( $n=4$ cages of 3 females/group) before pregnancy and in individually housed females ( $n=10$ /group) during gestation. b Nicotine intake before $(n=4)$ and during pregnancy $(n=10)$ was calculated based on 24-h fluid intake. c Plasma cotinine levels were determined by enzyme-linked immunosorbent assay (ELISA) after 4 weeks of nicotine ingestion. Plasma cotinine was detected in all nicotine-exposed females $(n=6)$ and was undetectable in non-exposed females $(n=6)$. $\mathbf{d}$ Twenty-fourhour food intake was determined in group-housed females ( $n=4$ cages of 3 females/group) before pregnancy. e Body weight was determined weekly before pregnancy ( $n=12 /$ group). Data were analyzed by two-way RM ANOVA followed by Bonferroni post-test (a) or by Mann-Whitney test $(\mathbf{c})(* *, p<0.01)$. All data are expressed as mean \pm SEM

and litter sizes were the same in both groups by PD21 (PNE: $4.2 \pm 1.02$; control: $4.5 \pm 0.8 ; n=10$ litters/group; $\mathrm{t}_{18}$ $=0.22, p=0.82 ; t$ test). However, PNE led to moderate decreases in mean body weight (PNE: $6.55 \pm 0.23 \mathrm{~g}$; control: $7.16 \pm 0.14 \mathrm{~g} ; n=42-45$ /group; $p=0.027$; Mann-Whitney test) and mean crown-rump length (PNE: $5.77 \pm 0.12 \mathrm{~cm}$; control: $6.15 \pm 0.45 \mathrm{~cm} ; \quad n=42-45 /$ group; $p=0.037$; Mann-Whitney test) of PD21 offspring. Therefore, to exclude differences in maternal care as a confounding factor in the assessment of the long-term metabolic consequences of PNE, we selected for the metabolic studies six nicotine-exposed litters and seven non-exposed litters showing similar postnatal survival rates (PNE: $85.7 \%$; control: $88.4 \%$ ), and without differences at PD21 in mean litter size (PNE: $5.7 \pm 0.7$; control: $5.4 \pm 0.5 ; \mathrm{t}_{11}=0.28, p=0.78 ; t$ test), mean body weight (PNE: $7.19 \pm 0.12 \mathrm{~g}$; control: $7.15 \pm$ 0.15 g; $n=34-38$ /group; $p=0.47$; Mann-Whitney test), and mean crown-rump length (PNE: $6.12 \pm 0.06 \mathrm{~cm}$; control: $6.16 \pm 0.08 \mathrm{~cm} ; n=34-38 /$ group; $p=0.41$; MannWhitney test).

\section{Prenatal nicotine exposure does not cause obesity or} type 2 diabetes in adult first-generation offspring Male offspring were subjected to a 16-week STD or HFD. PNE moderately decreased cumulative food intake of STD mice (PNE: $1268 \pm 9.5 \mathrm{kcal}, n=7$; control: 1363 $\pm 37.6 \mathrm{kcal}, n=8$ ) and HFD mice (PNE: $1416 \pm 13.48 \mathrm{kcal}$, $n=8$; control: $1450 \pm 27.6 \mathrm{kcal}, n=8$ ) (Fig. $2 \mathrm{a}$ ). Body weight measurements revealed no differences between PNE and control offspring fed the same diet (Fig. 2b). Moreover, PNE had no impact on body composition as determined by NMR measurements of relative fat, lean, and fluid mass (Fig. 2c-e). Plasma lipid levels were profiled in week 16 of the diets and were the same in nicotine-exposed and non-exposed offspring (Table 1).

To more accurately characterize PNE-induced changes in energy balance, we subjected individual male offspring in week 10 of the STD and HFD to simultaneous determinations of food intake, locomotor activity, and energy expenditure by indirect calorimetry in metabolic cages. PNE moderately reduced 24-h caloric intake of STD mice (PNE: $12.11 \pm 0.38 \mathrm{kcal} / 24 \mathrm{~h}, n=7$; control: 13.94 $\pm 0.52 \mathrm{kcal} / 24 \mathrm{~h}, n=7 ; \mathrm{t}_{12}=2.85$ and $p=0.015$ by $t$ test) and HFD mice (PNE: $14.21 \pm 0.34 \mathrm{kcal} / 24 \mathrm{~h}, n=8$; control: $17.16 \pm 1.16 \mathrm{kcal} / 24 \mathrm{~h}, n=7 ; \mathrm{F}_{1,25}=12.9$ and $p=$ 0.0014 by two-way ANOVA; $p<0.01$ by Bonferroni posttest) (Fig. 2f). PNE had no impact on 24-h energy expenditure, 24-h oxygen consumption, 24-h carbon dioxide production, or the respiratory exchange rate of offspring on the STD or HFD (Fig. $2 g-j$ ). However, we noted a moderate enhancement in 24-h vertical activity of PNE offspring relative to control offspring under HFD conditions, possibly reflecting increased rearing (Fig. $2 \mathrm{k}-\mathrm{l}$ ). HFD feeding reduced vertical and horizontal activities in 


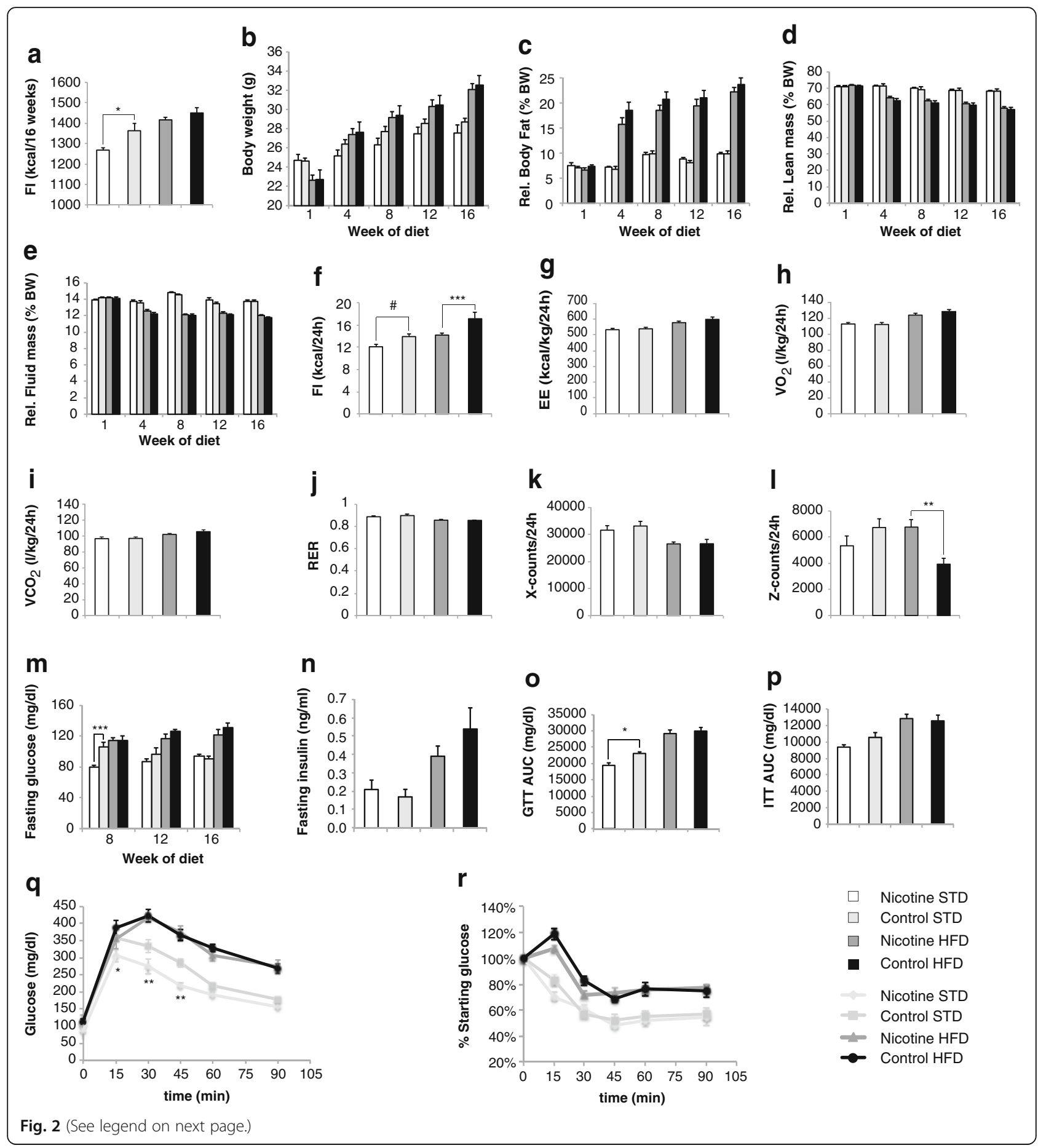


(See figure on previous page.)

Fig. 2 First-generation adult PNE offspring do not develop adiposity or type 2 diabetes. a Cumulative food intake of PNE offspring and control offspring (in kcal) was determined after 16 weeks of diet. b Monthly body weight measurements concomitant with body composition measurements. c-e Relative body fat (c), relative lean mass (d), and relative fluid mass (e) in \% of body weight (BW) determined monthly by nuclear magnetic resonance. $\mathbf{f}-\mathbf{I}$ metabolic cage measurements of 24-h food intake ( $\mathrm{FI})(\mathbf{f}), 24-\mathrm{h}$ energy expenditure (EE) (g), 24-h oxygen consumption rates $\left(\mathrm{VO}_{2}\right)$ (h), 24-h carbon dioxide production rates $\left(\mathrm{VCO}_{2}\right)(\mathbf{i})$, respiratory exchange ratio (RER) (j), and 24-h locomotor activity $(\mathbf{k}, \mathbf{I})$ in week 10 of the diets. $\mathrm{EE}, \mathrm{VO}_{2}$, and $\mathrm{VCO}_{2}$ were normalized to the lean mass determined by nuclear magnetic resonance prior to the start of the measurements. Locomotor activity was measured as horizontal (k) and vertical beam breaks counts (I). $\mathbf{m}$ Fasting glucose. $\mathbf{n}$ Fasting insulin determined in week 16 of the diets. o-p Area under the curve (AUC) determination of Glucose tolerance tests (GTT) conducted in week 6 of the diet (o) and Insulin tolerance tests (ITT) conducted in week 10 of the diets (p). q-r $\mathbf{r}$, Glucose concentration measurements during the GTT (q) and ITT (r). Mice were injected i.p. glucose $1 \mathrm{~g} / \mathrm{kg}(\mathbf{q})$ or Insulin $0.5 \mathrm{IU} / \mathrm{kg}(\mathbf{r})$. Data were analyzed by two-way ANOVA (a-p) or two-way RM ANOVA (q, $\mathbf{r}$ ) followed by Bonferroni posttests $\left({ }^{*}, p<0.05 ;{ }^{* *}, p<0.01 ;{ }^{* *}, p<0.001\right)$ or by $t$ test $(\mathbf{f})\left(^{*}, p<0.05\right)$. The number of male offspring in each group was $n=5-9$ originating from at least three different dams. All data are expressed as mean \pm SEM. HFD intake effectively rendered mice obese, diabetic and hypoactive $(\mathbf{a}-\mathbf{i}, \mathbf{k}-\mathbf{p}: p<0.005$, HFD vs. STD, two-way ANOVA)

control animals relative to STD feeding (Fig. $2 \mathrm{k}-\mathrm{l}$ ) as we have reported earlier $[6,49]$.

PNE offspring displayed a transient decrease in fasting glycemia in week 8 of the STD (PNE: $80.3 \pm 1.6 \mathrm{mg} / \mathrm{dl}$, $n=7$; control: $106.3 \pm 5.3 \mathrm{mg} / \mathrm{dl}, n=9 ; p<0.001$ by Bonferroni post-test) (Fig. 2m). Subsequent fasting glucose measurements in weeks 12 and 16 of the STD and in weeks 8,12 , and 16 of the HFD revealed no differences in fasting glycemia (Fig. 2m). A GTT conducted in week 8 of the diets revealed increased glucose tolerance in PNE offspring relative to control offspring under STD conditions (area under the curve (AUC): PNE, 19,348 \pm $751 \mathrm{mg} / \mathrm{dl}, n=7$; controls, $23,069 \pm 593 \mathrm{mg} / \mathrm{dl}, n=8$; $p<0.05$ by Bonferroni post-test) but not under HFD conditions (Fig. 2o, q). An ITT conducted in week 10 of the diets showed no difference in insulin sensitivity between PNE and control groups (Fig. 2p, r). Fasting plasma insulin concentrations determined in week 16 of the diets were similar in PNE and control offspring (Fig. 2n). We conclude that PNE did not render offspring more susceptible to obesity or diabetes development but instead moderately decreased food intake and fasting glycemia.

\section{Prenatal nicotine exposure enhances leptin-melanocortin signaling in adult first-generation offspring}

We measured the anorectic and body weight lowering actions of leptin and the MC3/4-R agonist MTII in prenatally nicotine-exposed and non-exposed adult firstgeneration offspring. Mice were fasted overnight, injected i.p. leptin, MTII, or vehicle (PBS), and immediately offered food, followed by determination of body weight and cumulative food consumption at defined time points [38].

Leptin administration examined the response of first order signaling neurons controlling food intake and body weight, including hypothalamic POMC neurons. Vehicle-injected and leptin-injected PNE offspring tended to gain less body weight than vehicle-injected and leptin-injected control offspring both under STD conditions $\left(\mathrm{t}=1 \mathrm{~h}: \mathrm{F}_{1,27}=4.71, p=0.04 ; \mathrm{t}=2 \mathrm{~h}: \mathrm{F}_{1,27}=\right.$ $14.5, p=0.0007 ; \mathrm{t}=8 \mathrm{~h}: \mathrm{F}_{1,27}=9.6, p=0.005 ; \mathrm{t}=24 \mathrm{~h}$ : $\mathrm{F}_{1,27}=9.9, p=0.004$; two-way ANOVA) (Fig. 3a) and HFD conditions $\left(\mathrm{t}=1 \mathrm{~h}: \mathrm{F}_{1,28}=7.9, p=0.009 ; \mathrm{t}=2 \mathrm{~h}\right.$ : $\mathrm{F}_{1,28}=3.3, p=0.08$; two-way ANOVA) (Fig. 3b). PNE offspring also tended to be more sensitive to leptinmediated inhibition of body weight gain under STD conditions ( $\mathrm{t}=2 \mathrm{~h}: \mathrm{t}_{14}=1.89, p=0.048 ; t$ test) (Fig. 3a) and HFD conditions ( $\mathrm{t}=1 \mathrm{~h}: \mathrm{t}_{14}=1.89, p=0.079 ; \mathrm{t}=2 \mathrm{~h}: \mathrm{t}_{14}=$ $2.21, p=0.045$; $t$ test) (Fig. 3b). Moreover, vehicle-injected PNE offspring gained less body weight than vehicleinjected control offspring both on the STD ( $\mathrm{t}=2 \mathrm{~h}: p<$ 0.05; $\mathrm{t}=8 \mathrm{~h}: p<0.01$; Bonferroni post-test) (Fig. 3a) and HFD ( $\mathrm{t}=1 \mathrm{~h}: \mathrm{t}_{14}=2.08, p=0.057 ; t$ test) (Fig. 3b). PNE did not impact food intake of vehicle-treated and leptintreated offspring on the STD (Fig. 3c) but moderately lowered food consumption of vehicle-treated and leptintreated offspring on the HFD ( $\mathrm{t}=1 \mathrm{~h}: \mathrm{F}_{1,28}=4.6, p=0.04$; two-way ANOVA). Furthermore, PNE modestly increased

Table 1 Plasma lipids

\begin{tabular}{lcccc}
\hline Lipid $(\mathrm{mg} / \mathrm{dl})$ & Nicotine STD & Control STD & Nicotine HFD & Control HFD \\
\hline Triglycerides & $48.1 \pm 5.4$ & $44.6 \pm 4.1$ & $61.9 \pm 5.4$ & $67.0 \pm 3.0^{*}$ \\
Cholesterol & $67.5 \pm 3.1$ & $64.7 \pm 1.4$ & $156.5 \pm 12.3^{* *}$ & $166.8 \pm 4.7^{* *}$ \\
HDL-Cholesterol & $50.6 \pm 3.6$ & $48.9 \pm 1.3$ & $124.3 \pm 3.0^{* *}$ & $125.9 \pm 1.6^{* *}$ \\
VLDL-Cholesterol & $9.6 \pm 1.2$ & $8.9 \pm 0.8$ & $12.4 \pm 1.0$ & $13.4 \pm 0.6^{*}$ \\
LDL-Cholesterol & $5.2 \pm 0.9$ & $7.2 \pm 1.1$ & $27.3 \pm 4.4^{* *}$ & $27.5 \pm 3.8^{* *}$ \\
\hline
\end{tabular}

Plasma lipids were determined in week 16 of the diets following $14 \mathrm{~h}$ overnight fasting using VITROS ${ }^{\odot}$ technology. Data were analyzed by two-way ANOVA followed by Bonferrroni post-test $\left({ }^{*}, p<0.01 ; * *, p<0.001\right.$ versus STD feeding). Each group consisted of $n=6-9$ male offspring from at least three different dams. Data are expressed as mean \pm SEM. HDL High density lipoprotein, $L D L$ Low density lipoprotein, VLDL Very low density lipoprotein 

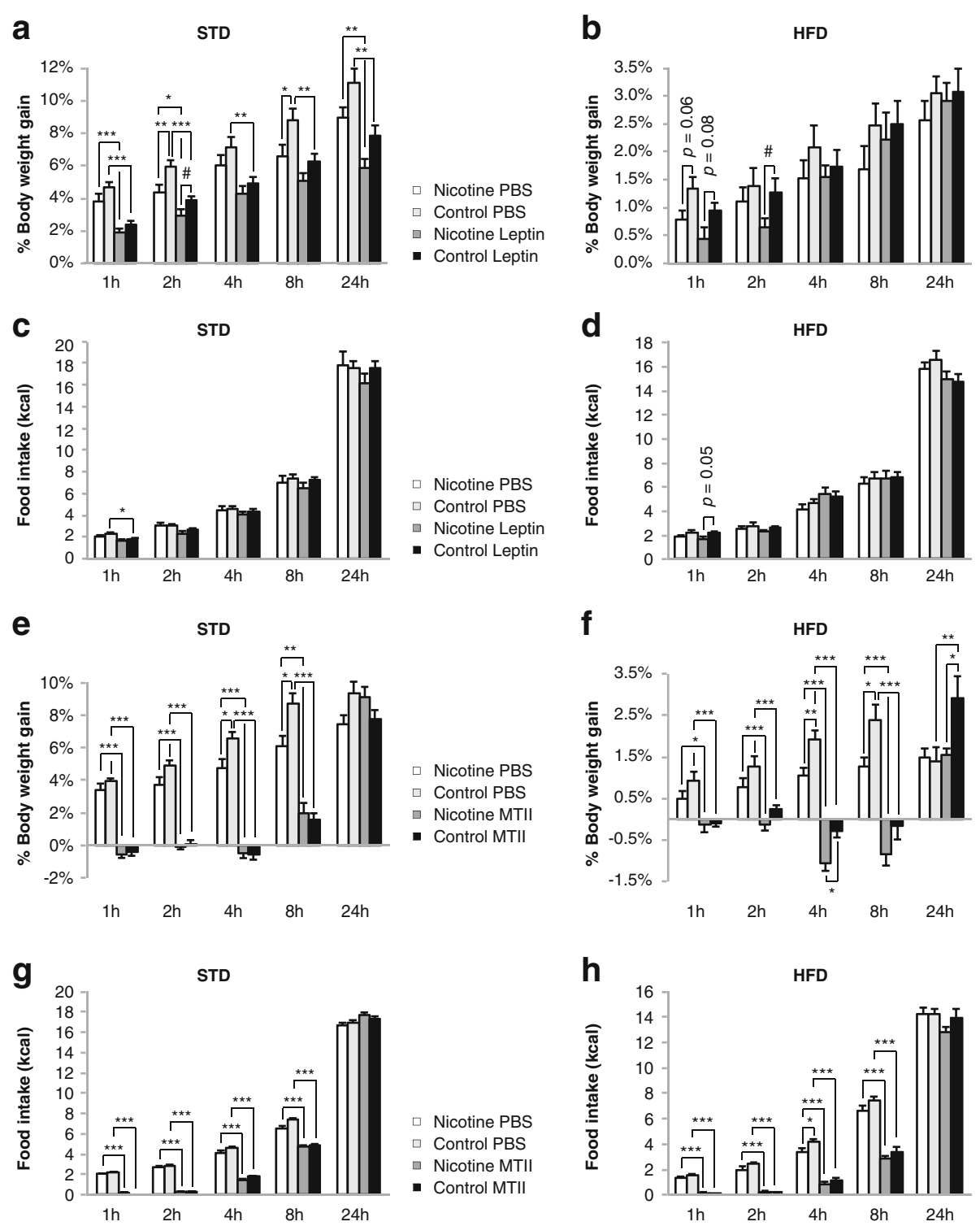

Fig. 3 PNE decreased body weight gain and moderately increased sensitivity to leptin-induced and melanotan II (MTII)-induced body weight loss of offspring in refeeding experiments. Male offspring were fasted for $12 \mathrm{~h}$, injected i.p. leptin ( $5 \mathrm{mg} / \mathrm{kg})$, MTIl (5 mg/kg), or vehicle (PBS), and immediately offered food. Body weight gain (\% of pre-injection body weight) and food intake were determined at defined time points post injection. a-d Leptin experiments: body weight change of STD mice (a) and HFD mice (b), cumulative food intake of STD mice (c) and HFD mice (d). e-h MTII experiments: body weight change of STD mice (e) and HFD mice (f), cumulative food intake of STD mice (g) and HFD mice (h). Data were analyzed by two-way ANOVA followed by Bonferroni post-tests $\left(*, p<0.05 ;{ }^{* *}, p<0.01 ;{ }^{* * *}, p<0.001\right)$ or unpaired two-tailed $t$ test: $\left({ }^{*}, p<0.05\right.$ and numerical $p$ values in $\mathbf{b}$ and $\mathbf{d}$ ). The number of male offspring in each group was $n=7-9$ originating from at least three different dams. All data are expressed as mean \pm SEM

sensitivity of HFD offspring to feeding inhibition by leptin $1 \mathrm{~h}$ after refeeding $\left(\mathrm{t}_{14}=2.11, p=0.054 ; t\right.$ test) (Fig. $3 \mathrm{~d}$ ).

MTII administration examined the response of second order signaling neurons controlling food intake and body weight including those innervated by hypothalamic POMC neurons. PNE tended to decrease body weight gain of MTII-injected and vehicle-injected offspring on the STD ( $\mathrm{t}=4 \mathrm{~h}: \mathrm{F}_{1,29}=2.9, p=0.099 ; \mathrm{t}=8 \mathrm{~h}: \mathrm{F}_{1,29}=2.89$, $p=0.099$; two-way ANOVA) (Fig. $3 \mathrm{e})$ and $\operatorname{HFD}(\mathrm{t}=2 \mathrm{~h}$ :
$\mathrm{F}_{1,28}=5.3, p=0.03 ; \mathrm{t}=4 \mathrm{~h}: \mathrm{F}_{1,28}=18.96, p<0.0001 ; \mathrm{t}=$ 8 h: $\mathrm{F}_{1,28}=9.3, p=0.005$; two-way ANOVA) (Fig. 3f). PNE and control offspring on the STD were equally sensitive to MTII-induced body weight loss (Fig. 3e). Under HFD conditions, PNE offspring were more sensitive to MTIIinduced body weight loss than control offspring $(\mathrm{t}=4 \mathrm{~h}$ : $p<0.05 ; \mathrm{t}=24 \mathrm{~h}: p<0.05$; Bonferroni post-test) (Fig. 3f). As we observed during the leptin sensitivity experiments, vehicle-injected PNE offspring gained less body weight 
than vehicle-injected control offspring under STD conditions $(\mathrm{t}=4 \mathrm{~h}: p<0.05 ; \mathrm{t}=8 \mathrm{~h}: p<0.05$; Bonferroni posttest) (Fig. 3e) and HFD conditions ( $\mathrm{t}=4 \mathrm{~h}: p<0.05$; $\mathrm{t}=$ 8 h: $p<0.01$; Bonferroni post-test) (Fig. 3f). Finally, PNE tended to moderately decrease food consumption of MTII-injected and vehicle-injected offspring on the STD $\left(\mathrm{t}=4 \mathrm{~h}: \mathrm{F}_{1,29}=5.1, p=0.03 ; \mathrm{t}=8 \mathrm{~h}: \mathrm{F}_{1,29}=3.8, p=0.06\right.$; two-way ANOVA) (Fig. $3 \mathrm{~g}$ ) and $\operatorname{HFD}\left(\mathrm{t}=4 \mathrm{~h}: \mathrm{F}_{1,28}=6.2\right.$, $p=0.02 ; \mathrm{t}=8 \mathrm{~h}: \mathrm{F}_{1,28}=3.4, p=0.08$; two-way ANOVA) (Fig. 3h).

In summary, the refeeding experiments showed that PNE decreased body weight gain of offspring and rendered them moderately more sensitive to the acute body weight lowering effects of leptin and MTII.

Most human obesity and animal models of dietinduced obesity are associated with elevated plasma leptin levels [50-52], and the development of resistance to leptin's body weight lowering actions [5]. Therefore, we measured plasma leptin concentrations as an indicator for hypothalamic leptin resistance. Plasma leptin concentrations were the same in PNE and control offspring on the STD (PNE: $0.9 \pm 0.09 \mathrm{ng} / \mathrm{ml}, n=7$; control: $0.98 \pm 0.18 \mathrm{ng} / \mathrm{ml}, n=9)$ but they were decreased in PNE offspring under HFD conditions (PNE, $9.3 \pm 1.07 \mathrm{ng} / \mathrm{ml}$, $n=9$; control, $14.85 \pm 2.21 \mathrm{ng} / \mathrm{ml}, n=7 ; p<0.01$ by Bonferroni post-test) (Fig. 4a). These results further suggest that PNE rendered offspring moderately more sensitive to leptin.

Leptin resistance is at least in part caused by impaired leptin signaling in the hypothalamus, including the POMC neurons $[5,52,53]$. To further examine whether PNE enhanced hypothalamic leptin signaling, we determined STAT3 phosphorylation (P-STAT3) in hypothalamic arcuate neurons $30 \mathrm{~min}$ after leptin i.p. injection. P-STAT3 immunoreactivity was assessed using a rabbit monoclonal (Fig. 4c) or a mouse monoclonal antibody recognizing STAT3 Tyr705 phosphorylation (Fig. 4d). PSTAT3 immunoreactivity was detected mainly in the hypothalamic arcuate nucleus (ARC) and to a minor extent in the ventromedial hypothalamic nucleus (VMH). Vehicle-injected offspring showed no P-STAT3 immunoreactivity in ARC and VMH consistent with previous observations [54, 55]. Leptin-injected PNE offspring showed a higher number of P-STAT3 positive arcuate neurons (mouse monoclonal P-STAT3 antibody: $31.1 \pm 3.4$ /section versus $8.02 \pm 3.01 /$ section, $n=3, \mathrm{t}_{4}=5.1, p=0.007, t$ test; rabbit monoclonal P-STAT3 antibody: $34.5 \pm 1.3$ /section versus $13.7 \pm 5.6 /$ section, $n=3, \mathrm{t}_{4}=3.66, p=0.02, t$ test) and tended to have a higher number of P-STAT3 positive POMC neurons $(9.8 \pm 3.4 /$ section versus $3.02 \pm 1.6 /$ section, $n=3, \mathrm{t}_{4}=1.8, p=0.14, t$ test) than leptin-injected control offspring (Fig. 4e, f, g). In PNE offspring, P-STAT3 reactivity was almost exclusively detected in the cell nuclei (Fig. 4c, d). In control offspring, P-STAT3 reactive nuclei were less intensely stained (Fig. 4c, d) and many cells with cytoplasmic P-STAT3 staining were detected in contrast to PNE offspring (Fig. 4c). These findings suggest that PNE offspring respond faster to leptininduced cytoplasmic-nuclear translocation of P-STAT3 and are consistent with enhanced hypothalamic leptinsignaling in PNE offspring.

Leptin stimulates P-STAT3 mediated transcription of POMC. To further determine the long-term effects of PNE on leptin signaling, we determined the levels of hypothalamic POMC mRNA at the end of the 16-week diet. PNE moderately increased POMC mRNA of adult male offspring under HFD but not under STD conditions $\left(\mathrm{F}_{1,28}=6.7, p=0.015\right.$ by two-way ANOVA; $p<0.05$ by Bonferroni post-test) (Fig. 4b) consistent with enhanced leptin-melanocortin signaling.

\section{Characterization of the coding and long non-coding transcriptome of hypothalamic POMC neurons}

Hypothalamic POMC neurons were isolated by laser microdissection from six prenatally nicotine-exposed and five non-exposed, STD-fed adult male offspring expressing the enhanced green fluorescent protein in POMC neurons [40]. A range of 400-600 POMC neurons were isolated from each mouse brain. Strand-specific RNAseq libraries were generated from these POMC neurons. A selective priming method during first strand cDNA synthesis minimized reverse transcription of ribosomal RNA (rRNA) sequences. Libraries were paired-end sequenced on Illumina's HiSeq2000 sequencer. Read-pairs were aligned to the mouse reference $\mathrm{mm} 10$ genome using STAR [41]. Only read-pairs aligning to a unique site of the mouse genome with less than two mismatches were used for analysis. Aligned read-pairs were run through HTSeq against the GENCODE reference gtf file vM4 for determination of read-pair counts by genes under consideration of DNA strand specificity [42]. Expression of a gene was normalized by dividing the number of read-pairs mapped to its exons by the number of read-pairs mapped to the reference genome. The resulting value was expressed in counts per million (CPM). Individual expression levels of alternative transcript variants were not quantified. For all analyses, only genes with average expression values across all samples $>1$ CPM were considered. Three expression calculators in edgeR [43], DESeq [44], and baySeq [45] determined differential gene expression. The intersection of differentially expressed features across these three calculators yielded the final list of differentially expressed genes.

Each library yielded on average 42.9 million read-pairs passing Illumina's quality control filters (PNE: 46.3 million; control: 38.8 million). On average, 30 million or $70.5 \%$ read-pairs per library were aligned to unique sites of the reference genome (PNE: 32.7 million or $71.3 \%$; 


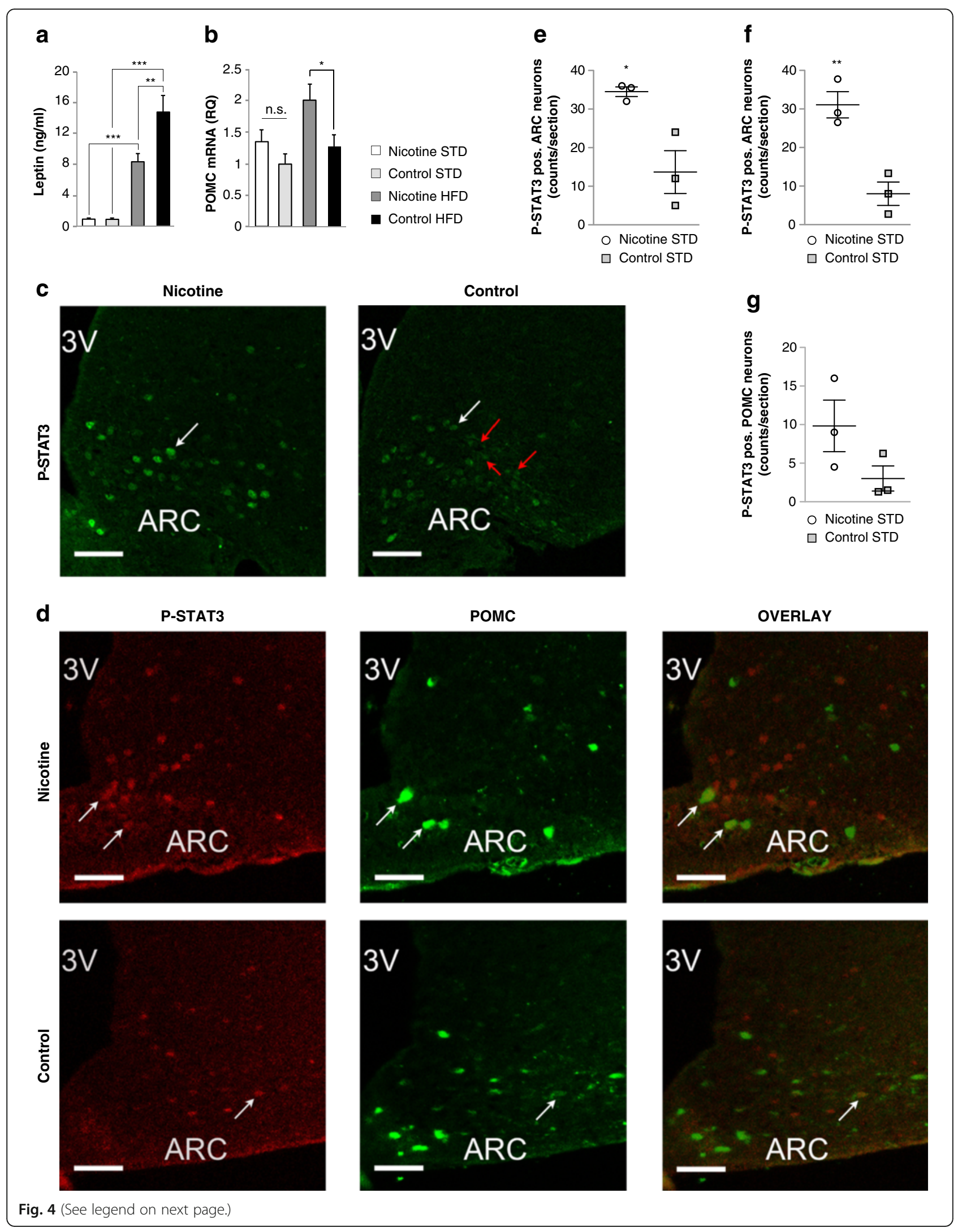




\section{(See figure on previous page.)}

Fig. 4 PNE enhanced hypothalamic leptin signaling in offspring. a Plasma leptin determined in week 16 of the diets. b Hypothalamic POMC mRNA levels were determined in week 16 of the diets by reverse transcription quantitative PCR, normalized to $\beta$-actin mRNA and expressed relative to the STD-fed control group. The number of male offspring in each group in (a) and (b) was $n=7-9$ originating from at least three different dams. $\mathbf{c}$, $\mathbf{d}$ Leptin-induced nuclear STAT3 phosphorylation (P-STAT3) of hypothalamic arcuate nucleus neurons (c, $\mathbf{d}$ ) and hypothalamic POMC neurons (d) determined in STD-fed mice by immunofluorescence using antibodies against STAT3-Tyr 705 phosphorylation and POMC polypeptide. P-STAT3 was detected using either a rabbit monoclonal (c) or mouse monoclonal antibody (d, left pane). Male offspring were fasted for $14 \mathrm{~h}$, injected i.p. leptin $(5 \mathrm{mg} / \mathrm{kg}$ ), and sacrificed 30 min post injection. White arrows highlight several P-STAT3 reactive nuclei in the hypothalamic arcuate nucleus (ARC) (c, $\mathbf{d}$, left panel), POMC positive neurons (d, middle panel), and POMC positive neurons with P-STAT3 reactive nuclei (d, right pane). Red arrows highlight neurons with cytoplasmic P-STAT3 immunoreactivity (c, right panel). $3 \mathrm{~V}$ refers to the third ventricle (c, d). The size bars represent $50 \mu \mathrm{M}$ (c, d). e, $\mathbf{f}$ Quantification of leptin-induced nuclear STAT3 phosphorylation in hypothalamic arcuate neurons after staining with rabbit monoclonal P-STAT3 antibody (e) or mouse monoclonal P-STAT3 antibody ( $\mathbf{f}$ ) $(n=3$ male offspring per group). $\mathbf{g}$ Quantification of P-STAT3 immunoreactive hypothalamic POMC neurons ( $n=3$ male offspring per group). Data were analyzed by two-way ANOVA followed by Bonferroni post-tests $\left({ }^{*}, p<0.05 ;{ }^{*}\right.$, $\left.p<0.01 ; *^{* *}, p<0.001\right)(\mathbf{a}, \mathbf{b})$ or by two-tailed $t$ test $(\mathbf{e}, \mathbf{f})$. All data are expressed as mean $\pm \mathrm{SEM}$

Control: 26.8 million or $69.4 \%$ ) (Table 2). Read-pairs mapped to 16,014 genes with average expression levels > 1 CPM (Additional file 1: Table S1). Of these, 13,539 (84.5\%) were protein-coding genes, 1708 (10.7\%) were ncRNA genes, and 767 (4.8 \%) were pseudogenes (Fig. 5a). NcRNA genes comprised 1124 (65.8 \%) lncRNA genes, 265 (15.5\%) short ncRNA genes, and 319 (18.7 \%) processed transcripts (Fig. 5b). Mapped lncRNA genes comprised 509 (45.3\%) lincRNA genes, 551 (49 \%) antisense RNA genes, 59 (5.2 \%) senseintronic RNA genes, four (0.4\%) sense-overlapping RNA genes, and one (0.1\%) 3'-overlapping ncRNA gene (Fig. 5c). Mapped short ncRNA genes were composed of

Table 2 RNA-seq alignment statistics

\begin{tabular}{lllc}
\hline Sample & \multicolumn{1}{l}{$\begin{array}{l}\text { Input read- } \\
\text { pairs }\end{array}$} & $\begin{array}{l}\text { Uniquely mapped } \\
\text { read-pairs }\end{array}$ & $\begin{array}{l}\text { Uniquely mapped } \\
\text { read-pairs (\%) }\end{array}$ \\
\hline N1 & $39,371,421$ & $28,694,853$ & 72.9 \\
N2 & $33,778,273$ & $23,411,127$ & 69.3 \\
N3 & $37,980,952$ & $26,573,624$ & 70.0 \\
N4 & $43,271,579$ & $31,630,187$ & 73.1 \\
N5 & $98,021,209$ & $67,023,419$ & 68.4 \\
N6 & $25,381,274$ & $18,901,075$ & 74.5 \\
C1 & $43,903,675$ & $28,076,176$ & 63.9 \\
C2 & $31,996,428$ & $22,462,184$ & 70.2 \\
C3 & $39,669,137$ & $26,617,656$ & 67.1 \\
C4 & $31,587,579$ & $23,443,335$ & 74.2 \\
C5 & $46,728,455$ & $33,418,612$ & 71.5 \\
Average & $42,880,907$ & $30,022,932$ & 70.5 \\
Average nicotine (n & $46,300,785$ & $32,705,714$ & 71.3 \\
=6) & & & 69.4 \\
Average control (n & $38,777,055$ & $26,803,593$ & \\
=5) & & & \\
\hline
\end{tabular}

Six PNE offspring (denoted as N1-N6) and five control offspring (denoted as C1-C5) were paired-end sequenced on Illuminas HiSeq2000 sequencer. Readpairs passing Illumina's internal quality filters (Input read-pairs) were aligned to the mouse mm10 reference genome using STAR [41]. Read-pairs mapped to a unique site of the mouse $\mathrm{mm} 10$ reference genome with less than two mismatches (Uniquely mapped read-pairs) were used for further analyses
116 (43.8 \%) microRNA (miRNA) genes, 81 (30.6 \%) small nucleolar RNA (snoRNAs) genes, 20 (7.5 \%) small nuclear RNA (snRNA) genes, ten (3.8 \%) rRNA genes, and 38 (14.3\%) miscellaneous RNA (miscRNA) genes (Fig. 5d). The fraction of expressed short ncRNA genes is likely underestimated because the RNA isolation procedure excluded RNAs smaller than 100 nucleotides. Antisense RNA genes expressed at levels $>1$ CPM were almost exclusively non-coding (551 or $99.8 \%$ ) and overlapped 529 (87.4\%) protein-coding genes, 61 (10.1 \%) ncRNA genes, and 15 (2.5\%) pseudogenes (Fig. 5f).

A total of 13,534 protein-coding genes with average expression levels $>1$ CPM were subjected to gene ontology (GO) classification using the PANTHER gene analysis tool [46]. PANTHER classified 12,731 proteincoding genes by molecular function, biological process, protein class, cellular component, and pathway. Most genes had binding $(3817 ; 33.1 \%)$, catalytic (3763; $32.7 \%)$, and transcription factor activity (1097; $9.5 \%)$ (Table 3), were involved in a metabolic $(5775 ; 50.1 \%)$ and cellular process $(3721 ; 32.3 \%$ ) (Table 4), encoded nucleic acid binding proteins $(1703 ; 14.8 \%)$ and transcription factors (1110; $9.6 \%$ ) (Table 5), and were associated with organelles $(679 ; 5.9 \%)$ and macromolecular complexes (437; 3.8 \%) (Table 6). GO classification by pathway detected the existence of numerous signaling and neurodevelopment pathways in hypothalamic POMC neurons (Fig. 6; Table 7; Additional file 2: Table S2). As expected, we found expression of 19 and 17 genes participating in the opioid proopiomelanocortin and enkephalin release pathways, respectively (Additional file 2: Table S2). Moreover, RNA-seq revealed expression of 40 genes participating in the nicotinic acetylcholine receptor signaling pathway including genes encoding the neuronal acetylcholine receptor subunit $\alpha-4$ (Chrna4), consistent with a previous report [10], the neuronal acetylcholine receptor subunit $\alpha-1$ (Chrna1), $\alpha-7$ (Chrna7), $\beta-1$ (Chrnb1), $\beta-2$ (Chrnb2), and acetylcholinesterase (Ache) (Additional file 2: Table S2). 


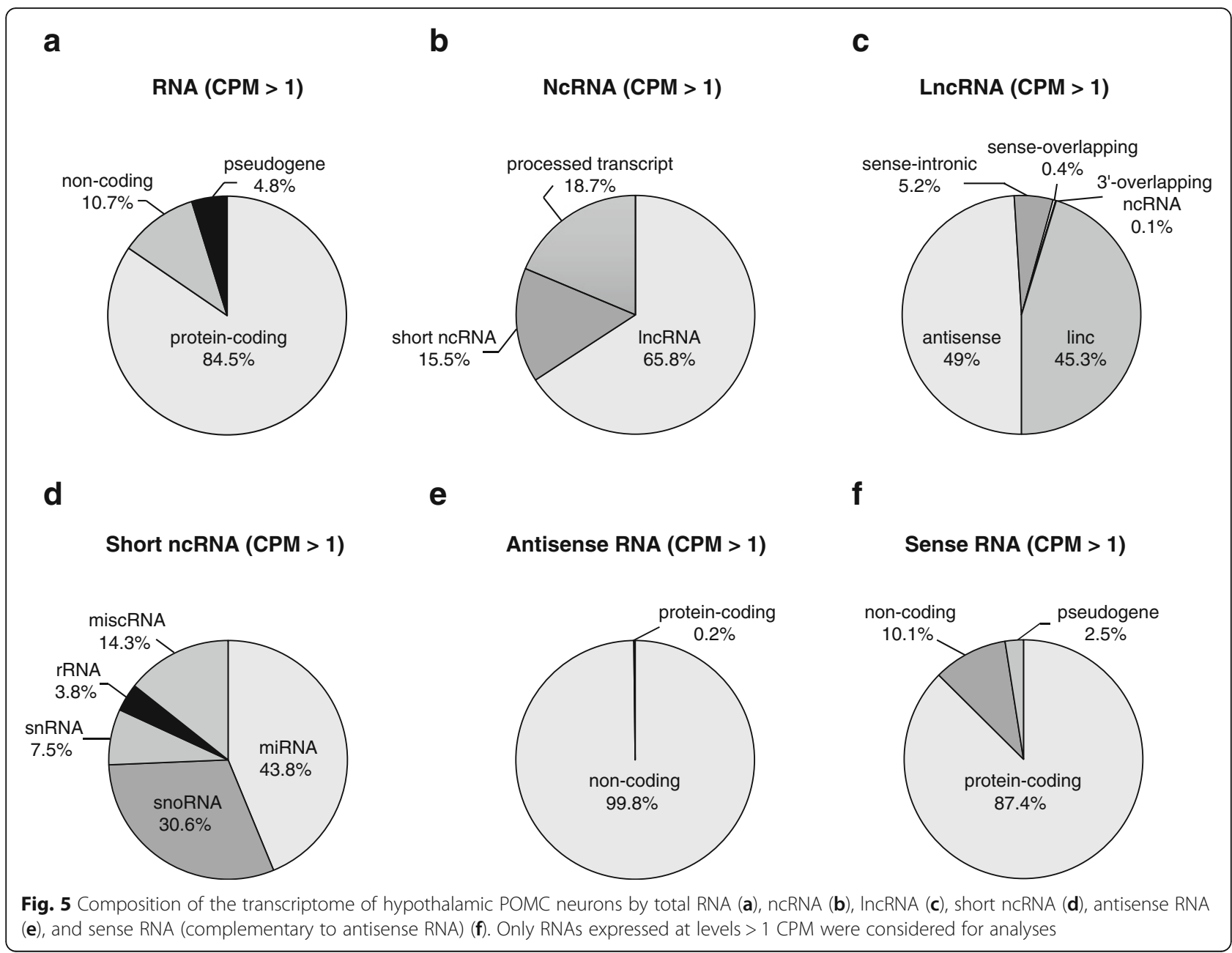

We also detected expression of various G-protein coupled receptor-signaling pathways that were previously reported to regulate feeding and body weight, to be expressed in POMC neurons and/or to regulate POMC neuronal activity. These included the dopamin receptor [56], oxytocin receptor [57], metabotropic glutamate receptor I-III $[58,59]$, ionotropic glutamate receptor, histamine $\mathrm{H} 1 / \mathrm{H} 2$ receptor [60], serotonin 1-4 (5HT1-4) receptor [61], GABA-B receptor II [62, 63], $\alpha$ adrenoceptor [64], $\beta 1-3$ adrenoceptor, and muscarinic acetylcholine receptor 1-4 pathways [65] (Fig. 6; Table 7; Additional file 2: Table S2).

POMC neurons expressed a synaptic vesicle trafficking pathway (Fig. 6; Table 7; Additional file 2: Table S2), the vesicular glutamate transporter 2 (vGlut2 or Slc17a6) and vesicular GABA transporter (vGat or Slc32a1), mediating uptake of glutamate and GABA/glycine into synaptic vesicles, respectively (Additional file 1: Table S1).

Moreover, we found expression of the insulin/insulin like growth factor (Igf) /protein kinase B (Akt), insulin/ Igf/mitogen activated protein kinase kinase (Mapkk)/ mitogen activated protein kinase (Mapk), and Jak/Stat signaling pathways in hypothalamic POMC neurons (Fig. 6; Table 7; Additional file 2: Table S2). RNA-seq also revealed expression of three key genes of the leptin receptor signaling pathway, the leptin receptor (Lepr), Jak2 and Stat 3 genes, and regulators of the leptin signaling pathway including suppressor of cytokine signaling 3 (Socs3) and protein tyrosine phosphatase $1 \mathrm{~b}$ (Ptpn1) (Additional file 1: Table S1).

POMC neurons also expressed various neuroendocrinesignaling pathways. These included the thyrotropinreleasing hormone (TRH) receptor, cortocotropin releasing factor (CRF) receptor, and gonadotropin releasing hormone $(\mathrm{GnRH})$ receptor signaling pathways (Fig. 6; Table 7; Additional file 2: Table S2). Moreover, we found expression of the fibroblast growth factor (FGF) signaling pathway and several fibroblast growth factors including Fgf1, Fgf9, Fgf12, Fgf13, and Fgf14 (Fig. 6; Table 7; Additional file 2: Table S2). POMC neurons also expressed several genes encoding core components of the circadian clock (Fig. 6; Table 7; Additional file 2: Table S2).

POMC neurons further expressed several neurodevelopment pathways. These included the netrin, Slit/Robo, 
Table 3 Gene Ontology classification of protein-coding genes by molecular function

\begin{tabular}{lccc}
\hline $\begin{array}{l}\text { Category name } \\
\text { (GO accession number) }\end{array}$ & $\begin{array}{l}\text { Number } \\
\text { of gene } \\
\text { hits }\end{array}$ & $\begin{array}{l}\text { Percent of gene } \\
\text { hit against total } \\
\text { number of genes }\end{array}$ & $\begin{array}{l}\text { Percent of gene } \\
\text { hit against total } \\
\text { number of } \\
\text { function hits }\end{array}$ \\
\hline $\begin{array}{l}\text { Antioxidant activity } \\
\text { (GO:0016209) }\end{array}$ & 18 & $0.20 \%$ & $0.10 \%$ \\
$\begin{array}{l}\text { Binding (GO:0005488) } \\
\text { Catalytic activity }\end{array}$ & 3817 & $33.10 \%$ & $31.70 \%$ \\
(GO:0003824) & 3763 & $32.70 \%$ & $31.20 \%$ \\
$\begin{array}{l}\text { Enzyme regulator activity } \\
\text { (GO:0030234) }\end{array}$ & 717 & $6.20 \%$ & $5.90 \%$ \\
$\begin{array}{l}\text { Nucleic acid binding } \\
\text { transcription factor } \\
\text { activity (GO:0001071) }\end{array}$ & 1097 & $9.50 \%$ & $9.10 \%$ \\
$\begin{array}{l}\text { Protein binding } \\
\text { transcription factor } \\
\text { activity (GO:0000988) }\end{array}$ & 147 & $1.30 \%$ & $1.20 \%$ \\
$\begin{array}{l}\text { Receptor activity } \\
\text { (GO:0004872) }\end{array}$ & 849 & $7.40 \%$ & $7.00 \%$ \\
$\begin{array}{l}\text { Structural molecule } \\
\text { activity (GO:0005198) }\end{array}$ & 786 & $6.80 \%$ & $6.50 \%$ \\
$\begin{array}{l}\text { Translation regulator } \\
\text { activity (GO:0045182) }\end{array}$ & 116 & $1.00 \%$ & $1.00 \%$ \\
$\begin{array}{l}\text { Transporter activity } \\
\text { (GO:0005215) }\end{array}$ & 745 & $6.50 \%$ & $6.20 \%$ \\
\hline
\end{tabular}

PANTHER classified 12,731 protein-coding genes with average expression values $>1$ CPM by molecular function. A total of 13,395 molecular functions were hit

and semaphorin axon guidance pathways, as well as the wnt, cadherin, integrin, transforming growth factor (TGF)- $\beta$, platelet derived growth factor (PDGF), and epidermal growth factor (EGF) pathways (Fig. 6; Table 7; Additional file 2: Table S2). Finally, RNA-seq detected expression of the Notch signaling and Alzheimer amyloid secretase pathways (Fig. 6; Table 7; Additional file 2: Table S2).

We ranked 1119 lncRNA genes (509 lincRNA, 551 antisense RNA, and 59 sense-intronic RNA genes) expressed at levels $>1 \mathrm{CPM}$ by expression (Additional file 3: Table S3). Of these, Yam1, Malat1, Meg3, Gm26870, Gm15564, 6330403K07Rik, Kcnq1ot1, Miat, A330023F24Rik, and Gm14703 were the most abundantly expressed lncRNAs (Additional file 3: Table S3). LncRNAs can regulate coding genes in cis through epigenetic, transcriptional, and post-transcriptional mechanism. To gain explorative insight into potential gene regulatory functions of IncRNAs expressed in POMC neurons, we assessed linear co-expression of lncRNAs (antisense RNA, lincRNA, sense-intronic RNA) with their nearest (adjacent or overlapping) protein-coding gene applying an expression threshold of 1 CPM for both, coding and non-coding gene expression. A Pearson's correlation coefficient $r>0.602$ or $<-0.602(n=11, p<0.05$ by
Table 4 Gene Ontology classification of protein-coding genes by biological process

\begin{tabular}{|c|c|c|c|}
\hline $\begin{array}{l}\text { Category name (GO } \\
\text { accession number) }\end{array}$ & $\begin{array}{l}\text { Number } \\
\text { of gene } \\
\text { hits }\end{array}$ & $\begin{array}{l}\text { Percent of gene } \\
\text { hit against total } \\
\text { number of genes }\end{array}$ & $\begin{array}{l}\text { Percent of gene } \\
\text { hit against total } \\
\text { number of } \\
\text { process hits }\end{array}$ \\
\hline $\begin{array}{l}\text { Apoptotic process } \\
\text { (GO:0006915) }\end{array}$ & 421 & $3.70 \%$ & $2.10 \%$ \\
\hline $\begin{array}{l}\text { Biological adhesion } \\
\text { (GO:0022610) }\end{array}$ & 556 & $4.80 \%$ & $2.80 \%$ \\
\hline $\begin{array}{l}\text { Biological regulation } \\
\text { (GO:0065007) }\end{array}$ & 2073 & $18.00 \%$ & $10.40 \%$ \\
\hline $\begin{array}{l}\text { Cellular component } \\
\text { organization or } \\
\text { biogenesis (GO:0071840) }\end{array}$ & 781 & $6.80 \%$ & $3.90 \%$ \\
\hline $\begin{array}{l}\text { Cellular process } \\
\text { (GO:0009987) }\end{array}$ & 3721 & $32.30 \%$ & $18.70 \%$ \\
\hline $\begin{array}{l}\text { Developmental process } \\
\text { (GO:0032502) }\end{array}$ & 1648 & $14.30 \%$ & $8.30 \%$ \\
\hline Growth (GO:0040007) & 3 & $0.00 \%$ & $0.00 \%$ \\
\hline $\begin{array}{l}\text { Immune system process } \\
\text { (GO:0002376) }\end{array}$ & 872 & $7.60 \%$ & $4.40 \%$ \\
\hline Localization (GO:0051179) & 1779 & $15.40 \%$ & $9.00 \%$ \\
\hline $\begin{array}{l}\text { Locomotion } \\
\text { (GO:0040011) }\end{array}$ & 7 & $0.10 \%$ & $0.00 \%$ \\
\hline $\begin{array}{l}\text { Metabolic process } \\
\text { (GO:0008152) }\end{array}$ & 5775 & $50.10 \%$ & $29.10 \%$ \\
\hline $\begin{array}{l}\text { Multicellular organismal } \\
\text { process (GO:0032501) }\end{array}$ & 1065 & $9.20 \%$ & $5.40 \%$ \\
\hline $\begin{array}{l}\text { Reproduction } \\
\text { (GO:0000003) }\end{array}$ & 306 & $2.70 \%$ & $1.50 \%$ \\
\hline $\begin{array}{l}\text { Response to stimulus } \\
\text { (GO:0050896) }\end{array}$ & 841 & $7.30 \%$ & $4.20 \%$ \\
\hline
\end{tabular}
(GO:0050896)

PANTHER classified 12,731 protein-coding genes with average expression values $>1$ CPM by biological process. A total of 21,970 biological processes were hit

two-tailed $t$ test) was regarded as significant. A total of 1053 lncRNA genes (452 lincRNA, 548 antisense RNA, and 53 sense-intronic RNA genes) and 991 protein-coding genes forming 1096 lncRNA/coding gene pairs were examined. We detected 82 co-expressed lncRNA/coding gene pairs comprising 41 antisense RNA/coding gene pairs, 34 lincRNA/coding gene pairs, and seven sense-intronic RNA/coding gene pairs (Additional file 4: Table S4). 59 (or $72 \%)$ lncRNA/protein-coding gene pairs were positively co-expressed whereas 23 (or $28 \%$ ) were negatively (discordantly) co-expressed. In over $75 \%$ of the co-expressed lncRNA/coding gene pairs, expression level of the lncRNA was less than $30 \%$ that of the coding gene. In the majority, 65 or $79 \%$, of lncRNA/coding gene pairs, the lncRNA overlapped the coding gene. Furthermore, in 29 or $35 \%$ of lncRNA/coding gene pairs, the lncRNA overlapped the coding gene promoter spanning the $10 \mathrm{~kb}$ sequence upstream of its first exon (Additional file 4: Table S4). 
Table 5 Gene Ontology classification of protein-coding genes by protein class

\begin{tabular}{|c|c|c|c|}
\hline $\begin{array}{l}\text { Category name } \\
\text { (PANTHER protein class } \\
\text { accession number) }\end{array}$ & $\begin{array}{l}\text { Number } \\
\text { of gene } \\
\text { hits }\end{array}$ & $\begin{array}{l}\text { Percent of gene } \\
\text { hit against total } \\
\text { number of genes }\end{array}$ & $\begin{array}{l}\text { Percent of gene } \\
\text { hit against total } \\
\text { number of } \\
\text { protein class hits }\end{array}$ \\
\hline $\begin{array}{l}\text { Calcium-binding protein } \\
\text { (PC00060) }\end{array}$ & 242 & $2.10 \%$ & $1.90 \%$ \\
\hline $\begin{array}{l}\text { Cell adhesion molecule } \\
\text { (PC00069) }\end{array}$ & 310 & $2.70 \%$ & $2.50 \%$ \\
\hline $\begin{array}{l}\text { Cell junction protein } \\
\text { (PC00070) }\end{array}$ & 104 & $0.90 \%$ & $0.80 \%$ \\
\hline Chaperone (PC00072) & 168 & $1.50 \%$ & $1.30 \%$ \\
\hline $\begin{array}{l}\text { Cytoskeletal protein } \\
\text { (PC00085) }\end{array}$ & 541 & $4.70 \%$ & $4.30 \%$ \\
\hline $\begin{array}{l}\text { Defense/immunity } \\
\text { protein (PC00090) }\end{array}$ & 238 & $2.10 \%$ & $1.90 \%$ \\
\hline $\begin{array}{l}\text { Enzyme modulator } \\
\text { (PC00095) }\end{array}$ & 981 & $8.50 \%$ & $7.90 \%$ \\
\hline $\begin{array}{l}\text { Extracellular matrix } \\
\text { protein (PC00102) }\end{array}$ & 289 & $2.50 \%$ & $2.30 \%$ \\
\hline Hydrolase (PC00121) & 1046 & $9.10 \%$ & $8.40 \%$ \\
\hline Isomerase (PC00135) & 116 & $1.00 \%$ & $0.90 \%$ \\
\hline Kinase (PC00137) & 400 & $3.50 \%$ & $3.20 \%$ \\
\hline Ligase (PC00142) & 350 & $3.00 \%$ & $2.80 \%$ \\
\hline Lyase (PC00144) & 131 & $1.10 \%$ & $1.00 \%$ \\
\hline $\begin{array}{l}\text { Membrane traffic } \\
\text { protein (PC00150) }\end{array}$ & 316 & $2.70 \%$ & $2.50 \%$ \\
\hline $\begin{array}{l}\text { Nucleic acid binding } \\
\text { (PC00171) }\end{array}$ & 1703 & $14.80 \%$ & $13.60 \%$ \\
\hline $\begin{array}{l}\text { Oxidoreductase } \\
\text { (PC00176) }\end{array}$ & 404 & $3.50 \%$ & $3.20 \%$ \\
\hline Phosphatase (PC00181) & 227 & $2.00 \%$ & $1.80 \%$ \\
\hline Protease (PC00190) & 337 & $2.90 \%$ & $2.70 \%$ \\
\hline Receptor (PC00197) & 872 & $7.60 \%$ & $7.00 \%$ \\
\hline $\begin{array}{l}\text { Signaling molecule } \\
\text { (PC00207) }\end{array}$ & 506 & $4.40 \%$ & $4.10 \%$ \\
\hline $\begin{array}{l}\text { Storage protein } \\
\text { (PC00210) }\end{array}$ & 9 & $0.10 \%$ & $0.10 \%$ \\
\hline $\begin{array}{l}\text { Structural protein } \\
\text { (PC00211) }\end{array}$ & 75 & $0.70 \%$ & $0.60 \%$ \\
\hline Surfactant (PC00212) & 28 & $0.20 \%$ & $0.20 \%$ \\
\hline $\begin{array}{l}\text { Transcription factor } \\
\text { (PC00218) }\end{array}$ & 1110 & $9.60 \%$ & $8.90 \%$ \\
\hline $\begin{array}{l}\text { Transfer/carrier protein } \\
\text { (PC00219) }\end{array}$ & 263 & $2.30 \%$ & $2.10 \%$ \\
\hline Transferase (PC00220) & 943 & $8.20 \%$ & $7.60 \%$ \\
\hline $\begin{array}{l}\text { Transmembrane } \\
\text { receptor regulatory/ } \\
\text { adaptor protein } \\
\text { (PC00226) }\end{array}$ & 58 & $0.50 \%$ & $0.50 \%$ \\
\hline Transporter (PC00227) & 715 & $6.20 \%$ & $5.70 \%$ \\
\hline Viral protein (PC00237) & 3 & $0.00 \%$ & $0.00 \%$ \\
\hline
\end{tabular}

Table 5 Gene Ontology classification of protein-coding genes by protein class (Continued)

\begin{tabular}{|c|c|c|c|}
\hline $\begin{array}{l}\text { Storage protein } \\
\text { (PC00210) }\end{array}$ & 9 & $0.10 \%$ & $0.10 \%$ \\
\hline $\begin{array}{l}\text { Structural protein } \\
\text { (PC00211) }\end{array}$ & 75 & $0.70 \%$ & $0.60 \%$ \\
\hline Urfactant (PC00212) & 28 & $0.20 \%$ & $0.20 \%$ \\
\hline $\begin{array}{l}\text { Transcription factor } \\
\text { (PC00218) }\end{array}$ & 1110 & $9.60 \%$ & $8.90 \%$ \\
\hline $\begin{array}{l}\text { Transfer/carrier protein } \\
\text { (PC00219) }\end{array}$ & 263 & $2.30 \%$ & $2.10 \%$ \\
\hline Transferase (PC00220) & 943 & $8.20 \%$ & $7.60 \%$ \\
\hline $\begin{array}{l}\text { Transmembrane } \\
\text { receptor regulatory/ } \\
\text { adaptor protein } \\
\text { (PC00226) }\end{array}$ & 58 & $0.50 \%$ & $0.50 \%$ \\
\hline Transporter (PC00227) & 715 & $6.20 \%$ & $5.70 \%$ \\
\hline Viral protein (PC00237) & 3 & $0.00 \%$ & $0.00 \%$ \\
\hline $\begin{array}{l}\text { Storage protein } \\
\text { (PC00210) }\end{array}$ & 9 & $0.10 \%$ & $0.10 \%$ \\
\hline $\begin{array}{l}\text { Structural protein } \\
\text { (PC00211) }\end{array}$ & 75 & $0.70 \%$ & $0.60 \%$ \\
\hline Surfactant (PC00212) & 28 & $0.20 \%$ & $0.20 \%$ \\
\hline $\begin{array}{l}\text { Storage protein } \\
\text { (PC00210) }\end{array}$ & 9 & $0.10 \%$ & $0.10 \%$ \\
\hline $\begin{array}{l}\text { Structural protein } \\
\text { (PC00211) }\end{array}$ & 75 & $0.70 \%$ & $0.60 \%$ \\
\hline Surfactant (PC00212) & 28 & $0.20 \%$ & $0.20 \%$ \\
\hline $\begin{array}{l}\text { Transcription factor } \\
\text { (PC00218) }\end{array}$ & 1110 & $9.60 \%$ & $8.90 \%$ \\
\hline $\begin{array}{l}\text { Transfer/carrier protein } \\
\text { (PC00219) }\end{array}$ & 263 & $2.30 \%$ & $2.10 \%$ \\
\hline Transferase (PC00220) & 943 & $8.20 \%$ & $7.60 \%$ \\
\hline $\begin{array}{l}\text { Transmembrane } \\
\text { receptor regulatory/ } \\
\text { adaptor protein } \\
\text { (PC00226) }\end{array}$ & 58 & $0.50 \%$ & $0.50 \%$ \\
\hline Transporter (PC00227) & 715 & $6.20 \%$ & $5.70 \%$ \\
\hline Viral protein (PC00237) & 3 & $0.00 \%$ & $0.00 \%$ \\
\hline
\end{tabular}

PANTHER classified 12,731 protein-coding genes with average expression values > 1 CPM by protein class. A total of 13,887 protein classes were hit

Since lncRNAs can be transcribed from enhancers as so-called enhancer RNAs (eRNAs) to stimulate gene transcription [66, 67], we determined whether lncRNAs that were co-expressed with their nearest protein-coding genes were transcribed from conserved mouse enhancers annotated in the VISTA enhancer browser database [68]. Only one IncRNA, Gm16263, an antisense RNA to the co-expressed protein-coding gene Fgf10, was transcribed from an annotated mouse enhancer. This enhancer spanned a region 1089 nucleotides upstream and 313 nucleotides downstream of the transcription start site of Fgf10 (mm10 build, chr13:118713610- 
Table 6 Gene Ontology classification of protein-coding genes by cellular component

\begin{tabular}{llll}
\hline $\begin{array}{l}\text { Category name } \\
\text { (GO accession } \\
\text { number) }\end{array}$ & $\begin{array}{l}\text { Number } \\
\text { of gene } \\
\text { hits }\end{array}$ & $\begin{array}{l}\text { Percent of gene } \\
\text { hit against total } \\
\text { number of genes }\end{array}$ & $\begin{array}{l}\text { Percent of gene hit } \\
\text { against total number of } \\
\text { cellular component hits }\end{array}$ \\
\hline $\begin{array}{l}\text { Cell junction } \\
\text { (GO:0030054) }\end{array}$ & 47 & $0.40 \%$ & $1.50 \%$ \\
$\begin{array}{l}\text { Cell part } \\
\text { (GO:0044464) }\end{array}$ & 1063 & $9.20 \%$ & $34.90 \%$ \\
$\begin{array}{l}\text { Extracellular } \\
\text { matrix } \\
\text { (GO:0031012) }\end{array}$ & 229 & $2.00 \%$ & $7.50 \%$ \\
$\begin{array}{l}\text { Extracellular } \\
\text { region }\end{array}$ & 314 & $2.70 \%$ & $10.30 \%$ \\
$\begin{array}{l}\text { (GO:0005576) } \\
\text { Macromolecular }\end{array}$ & 437 & $3.80 \%$ & $14.40 \%$ \\
$\begin{array}{l}\text { complex } \\
\text { (GO:0032991) }\end{array}$ & & & \\
$\begin{array}{l}\text { Membrane } \\
\text { (GO:0016020) }\end{array}$ & 272 & $2.40 \%$ & $8.90 \%$ \\
$\begin{array}{l}\text { Organelle } \\
\text { (GO:0043226) }\end{array}$ & 679 & $5.90 \%$ & $22.30 \%$ \\
$\begin{array}{l}\text { Synapse } \\
\text { (GO:0045202) }\end{array}$ & 4 & $0.00 \%$ & $0.10 \%$ \\
\hline PANTHR & & \\
\hline
\end{tabular}

PANTHER classified 12,731 protein-coding genes with average expression values $>1$ CPM by cellular component. Protein-coding genes hit a total of 3366 cellular components

118715012), thus overlapping the Fgf10 gene promoter and a small fragment of exon1 of Fgf10.

Co-expressed protein-coding genes had functions in nervous system development (Irx3, Msi2, Lhx1, Sox4, Plcb1), neurite outgrowth (Farp1, Lhx1, Ppp1r9a, Rapgef4, Srgap2), synaptogenesis (Cep112, Farp1, Fgf10, Myo6), neurotransmission (Hrh3, Gabra5, Plcb1, Rapgef4, Myo6, Kcna3, Kcna6, Kcnmb4), intracellular $\mathrm{Ca}^{2+}$ signaling (Pitpnm2, Slc8a3, Plcb1), insulin signaling (Irs4, Plcb1, Aspscr1, Baiap2l1), mitochondrial biogenesis, ubiquitin-dependent protein degradation, transcription regulation, RNA processing, cell cycle, cell division, cell growth, cell differentiation, cell adhesion, organization of the cytoskeleton, and apoptosis (Additional file 4: Table S4). Nineteen lncRNAs (A330102I10Rik, B930095G15Rik, Cep112os2, C030037D09Rik, Gm2727, Gm9962, Gm16006, Gm16263, Gm17180, Gm26673, Gm26814, Gm27008, Irx3os, Kcnmb4os1, Lhx1os, Rapgef4os3, RP24-302 F18.2, 9630028H03Rik, 2210017G18Rik) were co-expressed with the above-mentioned coding genes regulating nervous system development and function (Additional file 4: Table S4).

\section{Prenatal nicotine upregulates $\mathrm{Gm} 15851$ in adult offspring hypothalamic POMC neurons}

The intersection of the results of three differential expression calculators, edgeR, baySeq, and DESeq, revealed only one consistent expression difference between nicotine-exposed and non-exposed offspring, an 80-fold upregulation of Gm15851 in PNE offspring (FDR-adjusted $p$ value: 0.006 by edgeR, 0.002 by baySeq and DESeq; average expression level: 4.5 CPM). Two-way clustering revealed overlapping gene expression signatures of prenatally nicotine-exposed and non-exposed hypothalamic POMC neurons (Fig. 7a). Quantitative reverse transcription polymerase chain reaction (qRTPCR) confirmed upregulation of Gm15851 in POMC neurons of nicotine-exposed offspring $\left(t_{5}=3.17, p=\right.$ 0.025 by $t$ test with Welch's correction) (Fig. 7b). Gm15851 is a lncRNA of 662 nucleotides encoded by three exons on the forward strand of chromosome 1 (Fig. 7c). Supporting evidence for the existence of this transcript comes from one expressed sequence tag in the adult mouse male epididymis cDNA RIKEN full-length enriched library (RIKEN clone 9230112 L10) [21]. Gm15851 lacks a significant open reading frame. It is an antisense RNA overlapping two protein-coding genes, opticin (Optc) and proline arginine-rich end leucine-rich repeat (Prelp), on the reverse strand. The third exon of Gm15851 overlaps the second coding exon of Prelp whereas the first exon of Gm15851 overlaps the first intron of Optc (Fig. 7c). Although Optc and Prelp are potential targets of cis-regulation by Gm15851, both genes were not co-expressed with Gm15851 in POMC neurons.

\section{Discussion}

Contrary to expectations based on previous studies of gestational and neonatal nicotine exposure and energy balance, we report here that gestational nicotine exposure does not render offspring more susceptible to dietinduced obesity or type 2 diabetes. Instead, we found that gestational nicotine exposure moderately decreased food intake, body weight gain, and glycemia, and mildly increased sensitivity to leptin and melanocortin receptor stimulation in first-generation adult offspring. Consistent with a moderate enhancement in leptin sensitivity, PNE offspring were more sensitive to leptin-induced STAT3 phosphorylation, and-under HFD conditions-had increased POMC mRNA and decreased plasma leptin concentrations. Consistent with previous reports $[35,69]$, PNE offspring displayed increased voluntary locomotor activity under HFD conditions, which could reflect augmented exploratory behavior [69] or might result from enhanced central leptin-melanocortinergic signaling via POMC neurons as others and we have reported $[6,70]$. Interestingly, although food intake was moderately decreased and voluntary locomotion moderately increased under HFD feeding conditions, overall energy balance was unaffected in PNE offspring since neither body weights nor body fat content nor energy expenditure were measurably changed. It is possible that altered central regulation of body temperature in PNE offspring 


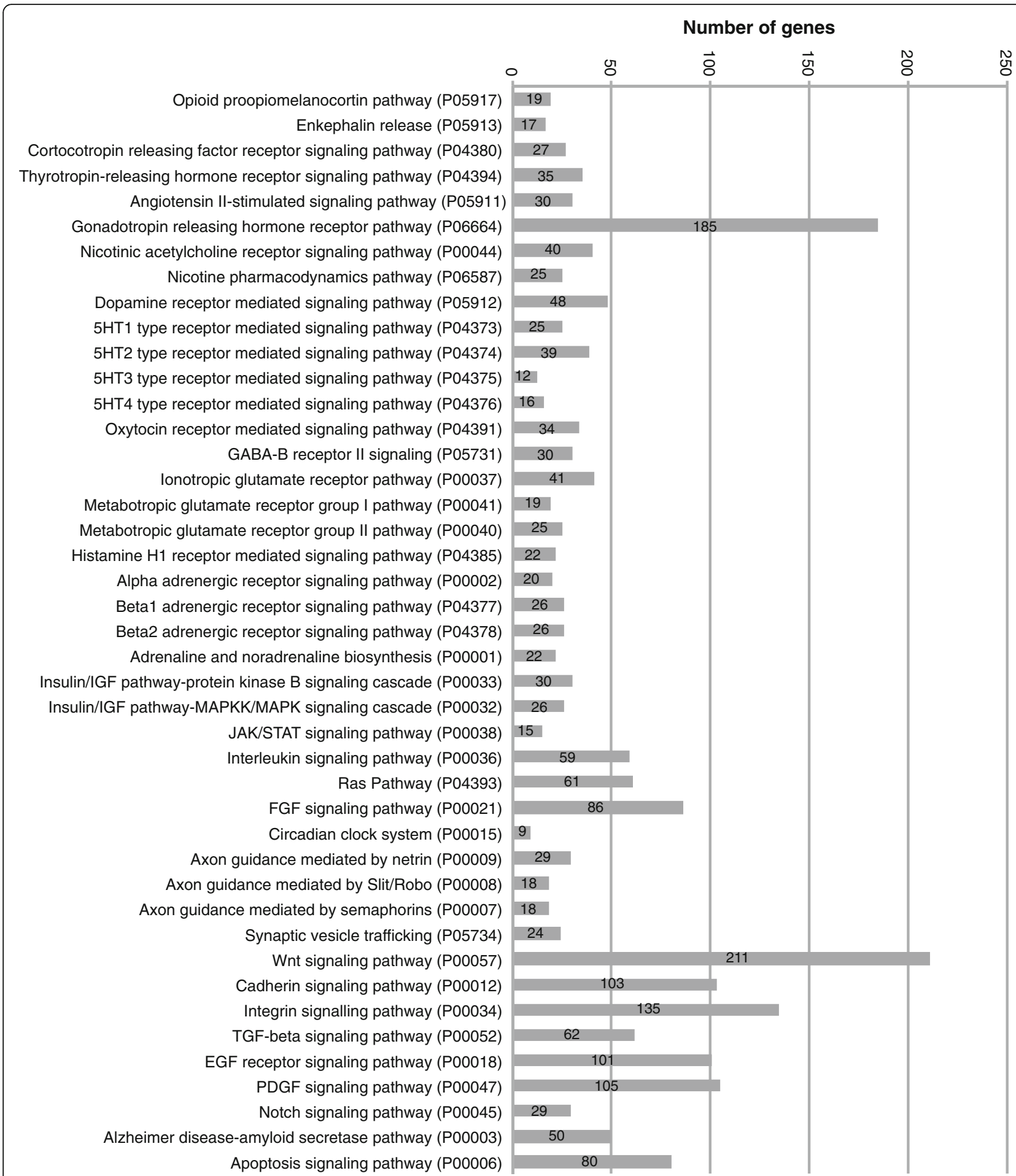

Fig. 6 Assignment of expressed genes to PANTHER defined pathways. The PANTHER pathway accession numbers and the number of mapped genes are indicated. Only genes expressed at levels > 1 CPM were considered

accounts for this outcome. Impaired central activation of brown fat thermogenesis could lead to compensatory hyperlocomotion to increase heat expenditure and preserve body temperature. Yet another possibility is that metabolic efficiency-the degree to which ingested food is being metabolized to perform work and generate heat-could be increased in PNE offspring. These alternative mechanisms require further investigation. 
Table 7 Gene Ontology classification of protein-coding genes by pathway

\begin{tabular}{|c|c|c|c|}
\hline Category name (PANTHER pathway accession number) & $\begin{array}{l}\text { Number of } \\
\text { gene hits }\end{array}$ & $\begin{array}{l}\text { Percent of gene hit against } \\
\text { total number of genes }\end{array}$ & $\begin{array}{l}\text { Percent of gene hit against total } \\
\text { number of pathway hits }\end{array}$ \\
\hline 2-arachidonoylglycerol biosynthesis (P05726) & 4 & $0.00 \%$ & $0.10 \%$ \\
\hline 5-Hydroxytryptamine biosynthesis (P04371) & 2 & $0.00 \%$ & $0.00 \%$ \\
\hline 5-Hydroxytryptamine degradation (P04372) & 3 & $0.00 \%$ & $0.10 \%$ \\
\hline 5HT1 type receptor mediated signaling pathway (P04373) & 25 & $0.20 \%$ & $0.60 \%$ \\
\hline 5HT2 type receptor mediated signaling pathway (P04374) & 39 & $0.30 \%$ & $1.00 \%$ \\
\hline 5HT3 type receptor mediated signaling pathway (P04375) & 12 & $0.10 \%$ & $0.30 \%$ \\
\hline 5HT4 type receptor mediated signaling pathway (P04376) & 16 & $0.10 \%$ & $0.40 \%$ \\
\hline Acetate utilization (P02722) & 3 & $0.00 \%$ & $0.10 \%$ \\
\hline Activin-beta signaling pathway (P06210) & 3 & $0.00 \%$ & $0.10 \%$ \\
\hline Adenine and hypoxanthine salvage pathway (P02723) & 6 & $0.10 \%$ & $0.10 \%$ \\
\hline Adrenaline and noradrenaline biosynthesis (P00001) & 22 & $0.20 \%$ & $0.50 \%$ \\
\hline Alanine biosynthesis (P02724) & 2 & $0.00 \%$ & $0.00 \%$ \\
\hline ALP23B_signaling_pathway (P06209) & 3 & $0.00 \%$ & $0.10 \%$ \\
\hline Alpha adrenergic receptor signaling pathway (P00002) & 20 & $0.20 \%$ & $0.50 \%$ \\
\hline Alzheimer disease-amyloid secretase pathway (P00003) & 50 & $0.40 \%$ & $1.20 \%$ \\
\hline Alzheimer disease-presenilin pathway (P00004) & 74 & $0.60 \%$ & $1.80 \%$ \\
\hline Aminobutyrate degradation (P02726) & 2 & $0.00 \%$ & $0.00 \%$ \\
\hline Androgen/estrogene/progesterone biosynthesis (P02727) & 3 & $0.00 \%$ & $0.10 \%$ \\
\hline Angiogenesis (P00005) & 125 & $1.10 \%$ & $3.10 \%$ \\
\hline $\begin{array}{l}\text { Angiotensin II-stimulated signaling through G proteins and } \\
\text { beta-arrestin (P05911) }\end{array}$ & 30 & $0.30 \%$ & $0.70 \%$ \\
\hline Apoptosis signaling pathway (P00006) & 80 & $0.70 \%$ & $2.00 \%$ \\
\hline Arginine biosynthesis (P02728) & 4 & $0.00 \%$ & $0.10 \%$ \\
\hline Ascorbate degradation (P02729) & 2 & $0.00 \%$ & $0.00 \%$ \\
\hline Asparagine and aspartate biosynthesis (P02730) & 4 & $0.00 \%$ & $0.10 \%$ \\
\hline ATP synthesis (P02721) & 6 & $0.10 \%$ & $0.10 \%$ \\
\hline Axon guidance mediated by netrin (P00009) & 29 & $0.30 \%$ & $0.70 \%$ \\
\hline Axon guidance mediated by semaphorins (P00007) & 18 & $0.20 \%$ & $0.40 \%$ \\
\hline Axon guidance mediated by Slit/Robo (P00008) & 18 & $0.20 \%$ & $0.40 \%$ \\
\hline B cell activation (P00010) & 49 & $0.40 \%$ & $1.20 \%$ \\
\hline Beta1 adrenergic receptor signaling pathway (P04377) & 26 & $0.20 \%$ & $0.60 \%$ \\
\hline Beta2 adrenergic receptor signaling pathway (P04378) & 26 & $0.20 \%$ & $0.60 \%$ \\
\hline Beta3 adrenergic receptor signaling pathway (P04379) & 11 & $0.10 \%$ & $0.30 \%$ \\
\hline Blood coagulation (P00011) & 22 & $0.20 \%$ & $0.50 \%$ \\
\hline BMP_signaling_pathway-drosophila (P06211) & 2 & $0.00 \%$ & $0.00 \%$ \\
\hline Cadherin signaling pathway (P00012) & 103 & $0.90 \%$ & $2.50 \%$ \\
\hline Carnitine and CoA metabolism (P02732) & 1 & $0.00 \%$ & $0.00 \%$ \\
\hline Carnitine metabolism (P02733) & 1 & $0.00 \%$ & $0.00 \%$ \\
\hline Cell cycle (P00013) & 17 & $0.10 \%$ & $0.40 \%$ \\
\hline Cholesterol biosynthesis (P00014) & 9 & $0.10 \%$ & $0.20 \%$ \\
\hline Circadian clock system (P00015) & 9 & $0.10 \%$ & $0.20 \%$ \\
\hline Coenzyme A biosynthesis (P02736) & 6 & $0.10 \%$ & $0.10 \%$ \\
\hline Cortocotropin releasing factor receptor signaling pathway (P04380) & 27 & $0.20 \%$ & $0.70 \%$ \\
\hline Cysteine biosynthesis (P02737) & 1 & $0.00 \%$ & $0.00 \%$ \\
\hline
\end{tabular}


Table 7 Gene Ontology classification of protein-coding genes by pathway (Continued)

Cytoskeletal regulation by Rho GTPase (P00016)

De novo purine biosynthesis (P02738)

De novo pyrimidine deoxyribonucleotide biosynthesis (P02739)

De novo pyrmidine ribonucleotides biosythesis (P02740)

DNA replication (P00017)

Dopamine receptor mediated signaling pathway (P05912)

DPP_signaling_pathway (P06213)

DPP-SCW_signaling_pathway (P06212)

EGF receptor signaling pathway (P00018)

Endogenous_cannabinoid_signaling (P05730)

Endothelin signaling pathway (P00019)

Enkephalin release (P05913)

FAS signaling pathway (P00020)

FGF signaling pathway (P00021)

Flavin biosynthesis (P02741)

Folate biosynthesis (P02742)

Formyltetrahydroformate biosynthesis (P02743)

Fructose galactose metabolism (P02744)

GABA-B_receptor_IIsignaling (P05731)

Gamma-aminobutyric acid synthesis (P04384)

GBB_signaling_pathway (P06214)

General transcription by RNA polymerase I (P00022)

General transcription regulation (P00023)

Glutamine glutamate conversion (P02745)

Glycolysis (P00024)

Gonadotropin releasing hormone receptor pathway (P06664)

Hedgehog signaling pathway (P00025)

Heme biosynthesis (P02746)

Heterotrimeric G-protein signaling pathway-Gi alpha and Gs alpha mediated pathway (P00026)

Heterotrimeric G-protein signaling pathway-Gq alpha and Go alpha mediated pathway (P00027)

Heterotrimeric G-protein signaling pathway-rod outer segment phototransduction (P00028)

Histamine $\mathrm{H} 1$ receptor mediated signaling pathway (P04385)

Histamine $\mathrm{H} 2$ receptor mediated signaling pathway (P04386)

Huntington disease (P00029)

Hypoxia response via HIF activation (P00030)

Inflammation mediated by chemokine and cytokine signaling pathway (P00031)

Insulin/IGF pathway-mitogen activated protein kinase kinase/MAP kinase cascade (P00032)

Insulin/IGF pathway-protein kinase B signaling cascade (P00033)

Integrin signalling pathway (P00034)

Interferon-gamma signaling pathway (P00035)

Interleukin signaling pathway (P00036)

lonotropic glutamate receptor pathway (P00037)
57

19

6

19

48

2

2

101

18

65

17

24

86

2

2

4

9

30

2

13

30

2

18

185

19

8

103

86

17

17

22

9

112

21

135

26

30

135

24

59

41
$0.50 \%$

$0.20 \%$

$0.10 \%$

$0.10 \%$

$0.20 \%$

$0.40 \%$

$0.00 \%$

$0.00 \%$

$0.90 \%$

$0.20 \%$

$0.60 \%$

$0.10 \%$

$0.20 \%$

$0.70 \%$

$0.00 \%$

$0.00 \%$

$0.00 \%$

$0.10 \%$

$0.30 \%$

$0.00 \%$

$0.00 \%$

$0.10 \%$

$0.30 \%$

$0.00 \%$

$0.20 \%$

$1.60 \%$

$0.20 \%$

$0.10 \%$

$0.90 \%$

$0.70 \%$

$0.10 \%$

$0.20 \%$

$0.10 \%$

$1.00 \%$

$0.20 \%$

$1.20 \%$

$0.20 \%$

$0.30 \%$

$1.20 \%$

$0.20 \%$

$0.50 \%$

$0.40 \%$
$1.40 \%$

$0.50 \%$

$0.10 \%$

$0.20 \%$

$0.50 \%$

$1.20 \%$

$0.00 \%$

$0.00 \%$

$2.50 \%$

$0.40 \%$

$1.60 \%$

$0.40 \%$

$0.60 \%$

$2.10 \%$

$0.00 \%$

$0.00 \%$

$0.10 \%$

$0.20 \%$

$0.70 \%$

$0.10 \%$

$0.00 \%$

$0.30 \%$

$0.70 \%$

$0.00 \%$

$0.40 \%$

$4.60 \%$

$0.50 \%$

$0.20 \%$

$2.50 \%$

$2.10 \%$

$0.40 \%$

$0.50 \%$

$0.20 \%$

$2.80 \%$

$0.50 \%$

$3.30 \%$

$0.60 \%$

$0.70 \%$

$3.30 \%$

$0.60 \%$

$1.50 \%$

$1.00 \%$ 
Table 7 Gene Ontology classification of protein-coding genes by pathway (Continued)

\begin{tabular}{|c|c|c|c|}
\hline Isoleucine biosynthesis (P02748) & 3 & $0.00 \%$ & $0.10 \%$ \\
\hline JAK/STAT signaling pathway (P00038) & 15 & $0.10 \%$ & $0.40 \%$ \\
\hline Leucine biosynthesis (P02749) & 2 & $0.00 \%$ & $0.00 \%$ \\
\hline Lipoate_biosynthesis (P02750) & 2 & $0.00 \%$ & $0.00 \%$ \\
\hline Mannose metabolism (P02752) & 5 & $0.00 \%$ & $0.10 \%$ \\
\hline Metabotropic glutamate receptor group I pathway (P00041) & 19 & $0.20 \%$ & $0.50 \%$ \\
\hline Metabotropic glutamate receptor group II pathway (P00040) & 25 & $0.20 \%$ & $0.60 \%$ \\
\hline Metabotropic glutamate receptor group III pathway (P00039) & 45 & $0.40 \%$ & $1.10 \%$ \\
\hline Methionine biosynthesis (P02753) & 2 & $0.00 \%$ & $0.00 \%$ \\
\hline Methylcitrate cycle (P02754) & 2 & $0.00 \%$ & $0.00 \%$ \\
\hline Methylmalonyl pathway (P02755) & 3 & $0.00 \%$ & $0.10 \%$ \\
\hline mRNA splicing (P00058) & 6 & $0.10 \%$ & $0.10 \%$ \\
\hline Muscarinic acetylcholine receptor 1 and 3 signaling pathway (P00042) & 38 & $0.30 \%$ & $0.90 \%$ \\
\hline Muscarinic acetylcholine receptor 2 and 4 signaling pathway (P00043) & 29 & $0.30 \%$ & $0.70 \%$ \\
\hline P53 pathway feedback loops 1 (P04392) & 5 & $0.00 \%$ & $0.10 \%$ \\
\hline P53 pathway feedback loops 2 (P04398) & 41 & $0.40 \%$ & $1.00 \%$ \\
\hline Parkinson disease (P00049) & 74 & $0.60 \%$ & $1.80 \%$ \\
\hline PDGF signaling pathway (P00047) & 105 & $0.90 \%$ & $2.60 \%$ \\
\hline Pentose phosphate pathway (P02762) & 7 & $0.10 \%$ & $0.20 \%$ \\
\hline Phenylethylamine degradation (P02766) & 1 & $0.00 \%$ & $0.00 \%$ \\
\hline PI3 kinase pathway (P00048) & 40 & $0.30 \%$ & $1.00 \%$ \\
\hline Plasminogen activating cascade (P00050) & 3 & $0.00 \%$ & $0.10 \%$ \\
\hline PLP biosynthesis (P02759) & 1 & $0.00 \%$ & $0.00 \%$ \\
\hline Proline biosynthesis (P02768) & 4 & $0.00 \%$ & $0.10 \%$ \\
\hline Purine metabolism (P02769) & 7 & $0.10 \%$ & $0.20 \%$ \\
\hline Pyridoxal phosphate salvage pathway (P02770) & 1 & $0.00 \%$ & $0.00 \%$ \\
\hline Pyrimidine Metabolism (P02771) & 8 & $0.10 \%$ & $0.20 \%$ \\
\hline Pyruvate metabolism (P02772) & 6 & $0.10 \%$ & $0.10 \%$ \\
\hline Ras Pathway (P04393) & 61 & $0.50 \%$ & $1.50 \%$ \\
\hline S adenosyl methionine biosynthesis (P02773) & 2 & $0.00 \%$ & $0.00 \%$ \\
\hline Salvage pyrimidine deoxyribonucleotides (P02774) & 1 & $0.00 \%$ & $0.00 \%$ \\
\hline Salvage pyrimidine ribonucleotides (P02775) & 6 & $0.10 \%$ & $0.10 \%$ \\
\hline SCW_signaling_pathway (P06216) & 2 & $0.00 \%$ & $0.00 \%$ \\
\hline Serine glycine biosynthesis (P02776) & 5 & $0.00 \%$ & $0.10 \%$ \\
\hline Succinate to proprionate conversion (P02777) & 2 & $0.00 \%$ & $0.00 \%$ \\
\hline Sulfate assimilation (P02778) & 2 & $0.00 \%$ & $0.00 \%$ \\
\hline Synaptic_vesicle_trafficking (P05734) & 24 & $0.20 \%$ & $0.60 \%$ \\
\hline T cell activation (P00053) & 58 & $0.50 \%$ & $1.40 \%$ \\
\hline TCA cycle (P00051) & 9 & $0.10 \%$ & $0.20 \%$ \\
\hline TGF-beta signaling pathway (P00052) & 62 & $0.50 \%$ & $1.50 \%$ \\
\hline Thiamine metabolism (P02780) & 3 & $0.00 \%$ & $0.10 \%$ \\
\hline Threonine biosynthesis (P02781) & 2 & $0.00 \%$ & $0.00 \%$ \\
\hline Thyrotropin-releasing hormone receptor signaling pathway (P04394) & 35 & $0.30 \%$ & $0.90 \%$ \\
\hline Toll receptor signaling pathway (P00054) & 39 & $0.30 \%$ & $1.00 \%$ \\
\hline Toll_pathway_drosophila (P06217) & 1 & $0.00 \%$ & $0.00 \%$ \\
\hline
\end{tabular}


Table 7 Gene Ontology classification of protein-coding genes by pathway (Continued)

\begin{tabular}{llll}
\hline Transcription regulation by bZIP transcription factor (P00055) & 41 & $0.40 \%$ & $1.00 \%$ \\
Triacylglycerol metabolism (P02782) & 1 & $0.00 \%$ & $0.00 \%$ \\
Tryptophan biosynthesis (P02783) & 1 & $0.00 \%$ & $0.00 \%$ \\
Tyrosine biosynthesis (P02784) & 1 & $0.00 \%$ & $0.00 \%$ \\
Ubiquitin proteasome pathway (P00060) & 50 & $0.40 \%$ & $1.20 \%$ \\
Valine biosynthesis (P02785) & 3 & $0.00 \%$ & $0.10 \%$ \\
Vasopressin synthesis (P04395) & 11 & $0.10 \%$ & $0.30 \%$ \\
VEGF signaling pathway (P00056) & 47 & $0.40 \%$ & $1.20 \%$ \\
Vitamin B6 metabolism (P02787) & 3 & $0.00 \%$ & $0.10 \%$ \\
Vitamin D metabolism and pathway (P04396) & 7 & $0.10 \%$ & $0.20 \%$ \\
Wnt signaling pathway (P00057) & 211 & $1.80 \%$ & $5.20 \%$ \\
Xanthine and guanine salvage pathway (P02788) & 4 & $0.00 \%$ & $0.10 \%$
\end{tabular}

PANTHER classified 12,731 protein-coding genes with average expression values $>1$ CPM by pathway. A total of 4445 pathways were hit

Furthermore, it remains to be clarified whether PNE has sexually dimorphic effects on the regulation of energy balance in offspring. Recently, Burke et al. reported that a subpopulation of hypothalamic arcuate POMC neurons, which express 5-hydroxytryptamine 2c receptors (5HT2CRs) and account for $40 \%$ of all hypothalamic arcuate $\mathrm{POMC}$ neurons, regulates energy balance in a sexually dimorphic manner [71]. The authors re-expressed POMC selectively in 5-HT2CR containing POMC neurons of POMC-deficient obese and insulin-resistant mice. Reexpression of POMC in this neuronal subpopulation was sufficient to normalize food intake, physical activity, brown fat heat expenditure, body weight, adiposity, and insulin sensitivity in males. Meanwhile, re-expression of POMC in this neuronal subpopulation in females corrected only food intake and insulin sensitivity but did neither increase physical activity, energy expenditure nor block the development of obesity [71].

Previous human epidemiological and meta-analysis studies [11-14] reported a positive correlation between PNE and the risk for obesity and type 2 diabetes in children and young adults. This correlation was further supported by rat studies of gestational and lactational nicotine exposure [15-18]. The onset, length, and route of nicotine administration likely determine the cumulative dose and developmental stage at which hypothalamic POMC neuronal progenitor cells are exposed to nicotine. Maternal plasma cotinine levels in the present and in previous rodent studies reporting metabolic disturbances in the offspring were of similar magnitude [15-17], suggesting that dams were exposed to comparable doses of nicotine. However, previous studies reporting diabetes in the offspring administered nicotine subcutaneously to dams [15-17, 72]. Nicotine that is subcutaneously administered to dams may reach the fetus at a higher concentration than maternally ingested nicotine because the former does not undergo first-pass hepatic conversion to cotinine contrary to the latter. In addition to differences in the route of administration, gestational nicotine exposure was continued throughout lactation in two studies reporting diabetes and obesity in the offspring $[15,17]$. Bruin et al. [72] showed that disturbances in glucose homeostasis in the offspring required nicotine exposure to occur both during gestation and lactation. This would be in line with the timing of development of murine hypothalamic arcuate neurons, which differentiate between embryonic days 10 and 16 [73] and form projections in the first three postnatal weeks to other hypothalamic regions involved in feeding regulation [74, 75]. Our observations suggest dosedependent and time-dependent effects of nicotine on developing hypothalamic POMC neurons. Exposure to nicotine at a low dose during gestation might stimulate proliferation, differentiation, neurite outgrowth, and synaptogenesis of developing hypothalamic POMC neurons, thereby sensitizing leptin-melanocortinergic signaling in adult offspring, whereas exposure to nicotine at a high dose during gestation and lactation might impair those processes, leading to the reported obesity and diabetes phenotypes in adult offspring.

RNA-seq of hypothalamic POMC neurons isolated from adult PNE and control offspring followed by differential expression analyses using three expression calculators detected only one consistent change, a nicotineinduced upregulation of Gm15851, an antisense RNA to the Prelp and Optc genes. Although Gm15851 was not co-expressed with Prelp or Optc in terminally differentiated POMC neurons, we cannot exclude that cis-regulatory interactions between Gm15851 and Prelp or Optc exist in POMC neuronal progenitor cells. LncRNAs may serve as scaffolds for gene-specific recruitment of transcription factors, transcriptional complexes, and/or chromatin-modifying complexes during specific developmental time windows. These additional regulators may 


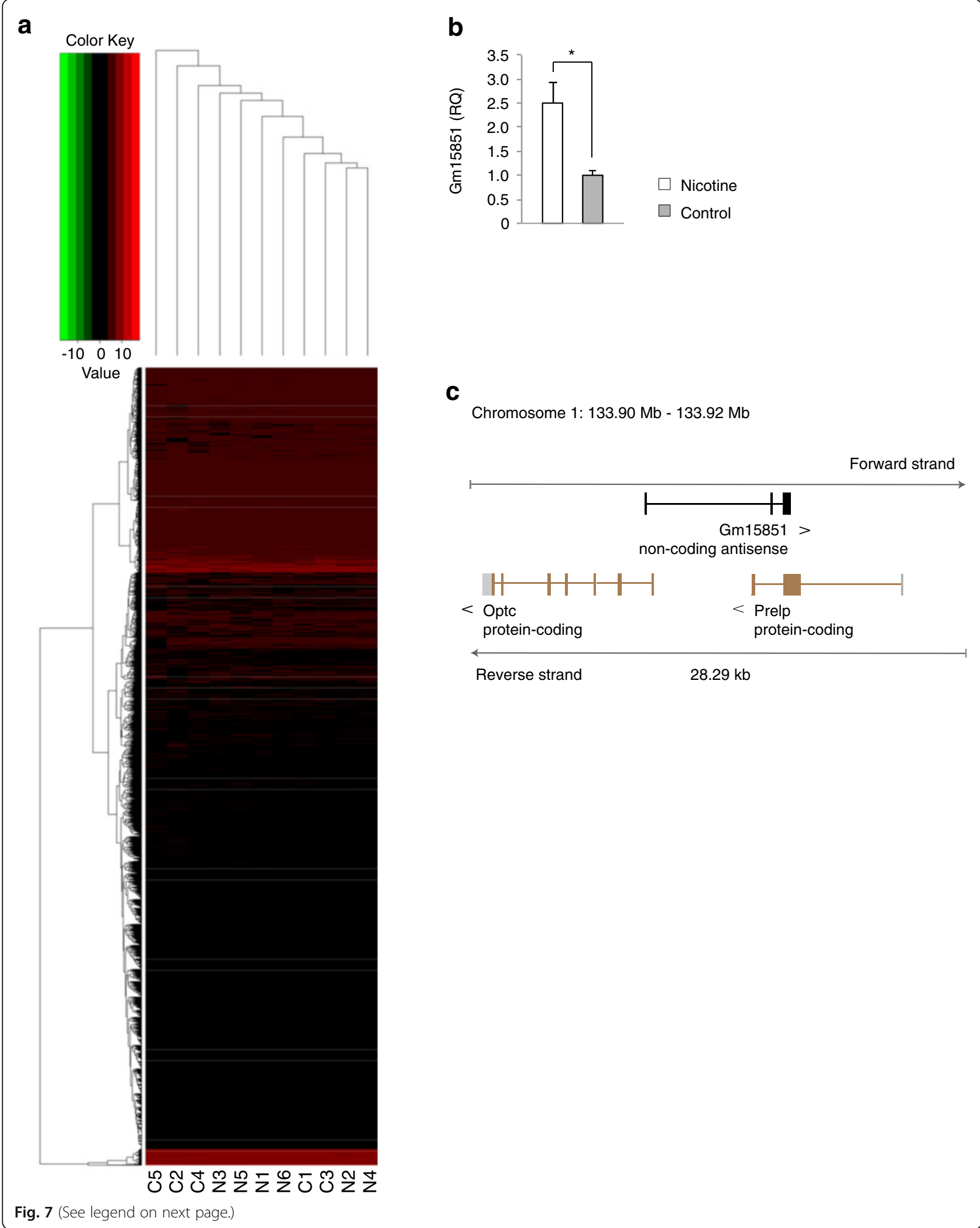


(See figure on previous page.)

Fig. 7 PNE upregulated an antisense RNA, Gm15851, in hypothalamic POMC neurons of adult offspring. a Two-way clustering of RNA-seq expression data of POMC neurons reveal overlapping gene expression signatures in PNE offspring (N1-N6) and control offspring (C1-C5). The color code represents the gene expression value in $\log _{2}$ CPM. Only genes with average expression levels $>1$ CPM across all offspring were considered. $\mathbf{b}$ Strand-specific qRTPCR confirms overexpression of Gm15851 in POMC neurons of PNE offspring $\left(^{*}, p<0.05, n=5-6\right.$, two-tailed $t$ test with Welch correction). c Schematic of genomic localization of Gm15851 within a $28.29 \mathrm{~kb}$ segment spanning the chromosomal coordinates $133.9 \mathrm{Mb}$ and $133.92 \mathrm{Mb}$ of chromosome 1 . Gm15851 is a spliced antisense transcript to Prelp and Optc on the forward strand of mouse chromosome 1. Boxes denote exons. Arrowheads denote gene orientation

not be expressed in terminally differentiated POMC neurons thus preventing regulatory interactions of Gm15851 with Optc and/or Prelp to be seen. It is possible that, in addition to regulation of transcription or chromatin state, Gm15851 might regulate post-transcriptional processes such as splicing, editing, translation, or localization of the Prelp or Optc RNA. Interestingly, Prelp and Optc both encode extracellular matrix proteins of the family of leucinerich repeat (LRR) domain-containing proteins. LRR domain containing proteins have been documented to organize axon guidance, target selection, and synapse formation [76]. Hence, it might be possible that Gm15851 could modulate the establishment of synaptic connections of POMC neuronal progenitor cells by regulating expression of Prelp and/or Optc.

Whole transcriptome sequencing of hypothalamic POMC neurons confirmed the expected expression of the Opioid proopiomelanocortin release pathways, known G-protein coupled receptor pathways regulating feeding and body weight, and the insulin receptor and leptin receptor signaling pathways. Furthermore, we confirmed expression of several nicotinic acetylcholine receptor subunits and acetylcholine metabolizing enzymes in POMC neurons [10]. We also detected expression of specific transport proteins (vGlut2 and vGat) required for the uptake of glutamate and GABA/glycine into synaptic vesicles, supporting the notion that POMC neurons release glutamate and GABA [77, 78].

Several neuroendocrine signaling pathways including those mediated by the GnRH, TRH, and CRF receptors were also expressed in POMC neurons. While POMC neurons regulate reproduction, energy expenditure and stress responses through activation of hypothalamic GnRH-producing, TRH-producing, and CRF-producing neurons, respectively, the reciprocal regulation of POMC neurons by these hormonal signaling pathways remains to be explored.

POMC neurons further expressed the netrin, slit, and semaphorin axon guidance pathways. Netrin, slit, and semaphorin are secreted or membrane-bound chemotropic proteins that attract or repulse growing axons and migrating neural progenitor cells by binding, respectively, to the unc, neuropilins, and plexin transmembrane receptors [79]. These proteins guide migration and neuronal outgrowth of hypothalamic oxytocin, antidiuretic hormone, and GnRH-producing neurons [80-82]. Furthermore, the slit/robo and semaphorin/plexin/neuropilin pathways are expressed during development of the hypothalamic PVN [83], an important projection site of POMC neurons. These cell migration and axon guidance pathways could therefore regulate migration of POMC neurons and formation of connections to relevant target sites.

In addition, we found expression of the wnt, integrin, cadherin, PDGF, EGF, and Notch signaling pathways in POMC neurons, all of which have been linked to the development of hypothalamic neurons. The wnt and integrin signaling pathways regulate differentiation of hypothalamic neuronal progenitor cells [84] and migration of hypothalamic GnRH producing neurons [85], respectively. Cadherin signaling regulates neuronal connectivity and wiring of hypothalamic POMC neurons [86, 87]. The Notch signaling pathway regulates differentiation of hypothalamic arcuate neural progenitor cells into POMC and AgRP neurons [88].

Furthermore, hypothalamic POMC neurons expressed an Alzheimer amyloid secretase and TGF- $\beta$ signaling pathway, which included expression of several TGF- $\beta$ encoding genes (TGF- $\beta 1$, TGF- $\beta 2$, TGF- $\beta 3$ ). Both pathways have been proposed to be disease-relevant. Excessive production of TGF- $\beta$ by POMC neurons was found to promote hypothalamic inflammation and type 2 diabetes in obesity and during aging [89]. Expression of an Alzheimer amyloid secretase pathway suggests participation of POMC neurons in the pathogenesis of diabetic comorbidities in Alzheimer's disease [90].

We attempted to gain insight into probable biological functions of expressed lncRNAs based on predicted cisregulatory interactions with protein-coding genes. This approach revealed 82 co-expressed lncRNA/coding gene pairs, 19 of which involved coding genes regulating neural development and/or function. Most co-expressed lncRNAs and coding genes overlapped each other. In around $35 \%$ of co-expressed lncRNA/coding gene pairs, the lncRNA also overlapped the coding gene promoter. These observations suggest that some of these lncRNAs could regulate chromatin state and/or promoter activity of the coding gene. Furthermore, we found that only one of the co-expressed IncRNAs was transcribed from an annotated conserved mouse enhancer. Such eRNAs are 
known to mediate gene-specific transcription by facilitating enhancer-promoter interactions, recruiting transcription factors, and blocking enhancer-binding of gene repressive factors $[66,67]$. Several co-expressed coding genes had annotated functions in nervous system development such as Irx3, Msi2 and Ppp1r9a. Irx3 is a homeobox transcription factor that is expressed in the prospective neural plate in a subset of neural precursor cells and possibly regulates specification of neural progenitor cells [91]. Msi1 is a neural RNA-binding protein that is highly enriched in neural precursor cells and drives proliferation of neurons and glial cells in the CNS during embryonic development [92], postnatally and in adults [93]. Ppp1r9a, also referred to as neurabin, is selectively expressed in neural tissues, where it induces F-actin crosslinking activity in the synapse and lamellipodia of the growth cone to regulate neurite formation [94].

\section{Conclusions}

Gestational nicotine exposure may not cause obesity and type 2 diabetes in first-generation offspring but instead may moderately enhance central leptin-melanocortinergic regulation of energy and glucose balance via POMC neurons. Gestational nicotine exposure upregulates Gm15851, a lncRNA, which might modulate POMC neuronal development and/or function. POMC neurons express 82 cis-regulatory lncRNA/protein-coding gene interactions, 19 of which involve coding genes regulating neural development and/or function, and several previously unidentified metabolic, neuroendocrine, and neurodevelopment pathways.

\section{Additional files}

Additional file 1: Table S1. Gene list. Read-pairs were aligned by STAR to the mouse reference genome. STAR alignments were run through HTSeq for determination of read-pair counts by genes. Genes are denoted by their Ensembl gene ID, gene symbol, and gene type (columns A-C). EdgeR calculated average gene expression values across all offspring (column D) and fold-changes between nicotine-exposed and control offspring ( $F C(N / C)$, column E). EdgeR (column F), baySeq (column G), and DESeq (column $\mathrm{H}$ ) determined differential gene expression. FDR false discovery rate-adjusted $p$ value, CPM counts per million. (XLSX $2364 \mathrm{~kb}$ )

Additional file 2: Table S2. Expressed protein-coding genes in PANTHER pathways. Expressed protein-coding genes denoted by Ensembl Gene ID (column A), gene name and symbol (column B), Panther family/ subfamily (column C), Panther protein class (column D), and average expression in CPM (column E) were assigned to PANTHER defined pathways, which are referred to by name and accession number. Only genes expressed at levels > 1 CPM were considered for analysis. CPM counts per million. (XLSX $172 \mathrm{~kb})$

Additional file 3: Table S3. Expression ranking of IncRNAs in POMC neurons. LncRNA genes referred to by Ensembl Gene ID (column A), gene name (column B), and gene type (column C) were ranked by average expression across all samples (column D). Only IncRNA genes expressed at levels $>1$ CPM were considered for analysis. CPM counts per million. (XLSX $98 \mathrm{~kb}$ )

Additional file 4: Table S4. Co-expressed IncRNAs and protein-coding genes in cis. Co-expression of IncRNAs (columns A and B) with their nearest (adjacent or overlapping) protein-coding gene (column D) was determined by the Pearson's correlation coefficient $r$ (column F). An $r$ value $>$ 0.602 or $<-0.602$ was regarded as significant $(p<0.05$, two-tailed $t$ test, $n=11$ ). Co-expressed IncRNA/protein-coding gene pairs are ranked by the absolute $r$ value. A positive $r$ value indicates positive correlation and a negative $r$ value indicates negative correlation (column G). The distance between IncRNA and protein-coding gene (column $\mathrm{H}$ ) was defined as the distance between their nearest borders irrespective of strand orientation (columns C, E) and was set 0 for overlapping IncRNAs and protein-coding genes. LncRNAs were positioned upstream, overlapping, and/or downstream of the coding gene body (column I). A number of IncRNAs overlapped the coding gene promoter (column J) defined as the $10 \mathrm{~kb}$ upstream sequence of a gene. Only IncRNA and coding genes with average expression levels > 1 CPM (columns $\mathrm{K}$ and L) were considered for analyses. LncRNA expression was in most cases less than that of the coding gene (column M). Coding genes function in various biological processes (column N). (XLSX $63 \mathrm{~kb})$

\section{Acknowledgements}

Not applicable.

\section{Funding}

This work was funded by the James and Esther King Biomedical Research Program, Florida Department of Health, Florida, USA, grant number 3KN06.

\section{Availability of data and materials}

The BAM files supporting the RNA-seq results are available in the Sequence Read Archive database (SRA) (http://www.ncbi.nlm.nih.gov/sra) under accession number SRP070178.

\section{Authors' contributions}

J.P.S. conceived, designed and conducted the research, analyzed the phenotypic and bioinformatics data, and wrote the manuscript. G.L. conducted the research. D.V.B. analyzed the bioinformatics data. C.W. wrote the manuscript. All authors read and approved the final manuscript.

\section{Competing interests}

The authors declare that they have no competing interests.

\section{Consent for publication}

Not applicable.

\section{Ethics approval}

Care of mice and animal procedures were conducted with the approval of the Institutional Animal Care and Use Committee of the University of Miami.

\section{Author details}

'Department of Psychiatry and Behavioral Sciences and Center for Therapeutic Innovation, Miller School of Medicine, University of Miami, Miami, FL 33136, USA. ${ }^{2}$ John P. Hussman Institute for Human Genomics, Miller School of Medicine, University of Miami, Miami, FL 33136, USA.

Received: 18 April 2016 Accepted: 23 August 2016

Published online: 08 September 2016

\section{References}

1. Woods SC, Schwartz MW, Baskin DG, Seeley RJ. Food intake and the regulation of body weight. Annu Rev Psychol. 2000;51:255-77.

2. Ahima RS, Saper CB, Flier JS, Elmquist JK. Leptin regulation of neuroendocrine systems. Front Neuroendocrinol. 2000;21:263-307.

3. Kitamura T, Feng Y, Kitamura YI, Chua Jr SC, Xu AW, Barsh GS, et al. Forkhead protein FoxO1 mediates Agrp-dependent effects of leptin on food intake. Nat Med. 2006;12:534-40.

4. Breen TL, Conwell IM, Wardlaw SL. Effects of fasting, leptin, and insulin on AGRP and POMC peptide release in the hypothalamus. Brain Res. 2005;1032:141-8.

5. Enriori PJ, Evans AE, Sinnayah P, Jobst EE, Tonelli-Lemos L, Billes SK, et al. Diet-induced obesity causes severe but reversible leptin resistance in arcuate melanocortin neurons. Cell Metab. 2007;5:181-94. 
6. Huo L, Gamber K, Greeley S, Silva J, Huntoon N, Leng XH, et al. Leptindependent control of glucose balance and locomotor activity by POMC neurons. Cell Metab. 2009;9:537-47.

7. Vaisse C, Clement K, Durand E, Hercberg S, Guy-Grand B, Froguel P. Melanocortin-4 receptor mutations are a frequent and heterogeneous cause of morbid obesity. J Clin Investig. 2000;106:253-62.

8. Krude H, Gruters A. Implications of proopiomelanocortin (POMC) mutations in humans: the POMC deficiency syndrome. Trends Endocrinol Metab. 2000;11:15-22

9. Faroogi IS, O'Rahilly S. Monogenic human obesity syndromes. Recent Prog Horm Res. 2004;59:409-24.

10. Mineur YS, Abizaid A, Rao Y, Salas R, DiLeone RJ, Gundisch D, et al. Nicotine decreases food intake through activation of POMC neurons. Science. 2011;332:1330-2

11. Montgomery SM, Ekbom A. Smoking during pregnancy and diabetes mellitus in a British longitudinal birth cohort. BMJ. 2002;324:26-7.

12. Oken E, Levitan EB, Gillman MW. Maternal smoking during pregnancy and child overweight: systematic review and meta-analysis. Int J Obes. 2008;32:201-10.

13. Power $C$, Jefferis BJ. Fetal environment and subsequent obesity: a study of maternal smoking. Int J Epidemiol. 2002;31:413-9.

14. Toschke AM, Koletzko B, Slikker Jr W, Hermann M, von Kries R. Childhood obesity is associated with maternal smoking in pregnancy. Eur J Pediatr. 2002;161:445-8.

15. Gao YJ, Holloway AC, Zeng ZH, Lim GE, Petrik JJ, Foster WG, et al. Prenatal exposure to nicotine causes postnatal obesity and altered perivascular adipose tissue function. Obes Res. 2005;13:687-92.

16. Somm E, Schwitzgebel VM, Vauthay DM, Camm EJ, Chen CY, Giacobino JP, et al. Prenatal nicotine exposure alters early pancreatic islet and adipose tissue development with consequences on the control of body weight and glucose metabolism later in life. Endocrinology. 2008;149:6289-99.

17. Holloway AC, Lim GE, Petrik JJ, Foster WG, Morrison KM, Gerstein HC. Fetal and neonatal exposure to nicotine in Wistar rats results in increased beta cell apoptosis at birth and postnatal endocrine and metabolic changes associated with type 2 diabetes. Diabetologia. 2005;48:2661-6.

18. Oliveira E, Moura EG, Santos-Silva AP, Fagundes AT, Rios AS, Abreu-Villaca Y, et al. Short- and long-term effects of maternal nicotine exposure during lactation on body adiposity, lipid profile, and thyroid function of rat offspring. J Endocrinol. 2009:202:397-405.

19. Grove KL, Sekhon HS, Brogan RS, Keller JA, Smith MS, Spindel ER. Chronic maternal nicotine exposure alters neuronal systems in the arcuate nucleus that regulate feeding behavior in the newborn rhesus macaque. J Clin Endocrinol Metabol. 2001:86:5420-6.

20. Huang LZ, Winzer-Serhan UH. Nicotine regulates mRNA expression of feeding peptides in the arcuate nucleus in neonatal rat pups. Dev Neurobiol. 2007:67:363-77.

21. Carninci P, Kasukawa T, Katayama S, Gough J, Frith MC, Maeda N, et al. The transcriptional landscape of the mammalian genome. Science. 2005;309:1559-63

22. Djebali S, Davis CA, Merkel A, Dobin A, Lassmann T, Mortazavi A, et al. Landscape of transcription in human cells. Nature. 2012;489:101-8.

23. Wahlestedt C. Natural antisense and noncoding RNA transcripts as potential drug targets. Drug Discov Today. 2006;11:503-8.

24. Cabili MN, Trapnell C, Goff L, Koziol M, Tazon-Vega B, Regev A, et al. Integrative annotation of human large intergenic noncoding RNAs reveals global properties and specific subclasses. Gene Dev. 2011;25:1915-27.

25. Derrien T, Johnson R, Bussotti G, Tanzer A, Djebali S, Tilgner H, et al. The GENCODE v7 catalog of human long noncoding RNAs: analysis of their gene structure, evolution, and expression. Genome Res. 2012;22:1775-89.

26. Faghihi MA, Wahlestedt C. Regulatory roles of natural antisense transcripts. Nat Rev Mol Cell Biol. 2009;10:637-43.

27. Rinn JL, Chang HY. Genome regulation by long noncoding RNAs. Ann Rev Biochem. 2012;81:145-66.

28. Dinger ME, Amaral PP, Mercer TR, Pang KC, Bruce SJ, Gardiner BB, et al. Long noncoding RNAs in mouse embryonic stem cell pluripotency and differentiation. Genome Res. 2008;18:1433-45.

29. Guttman M, Donaghey J, Carey BW, Garber M, Grenier JK, Munson G, et al. lincRNAs act in the circuitry controlling pluripotency and differentiation. Nature. 2011:477:295-300.

30. Mercer TR, Qureshi IA, Gokhan S, Dinger ME, Li G, Mattick JS, et al. Long noncoding RNAs in neuronal-glial fate specification and oligodendrocyte lineage maturation. BMC Neurosci. 2010;11:14.
31. Guttman M, Amit I, Garber M, French C, Lin MF, Feldser D, et al. Chromatin signature reveals over a thousand highly conserved large non-coding RNAs in mammals. Nature. 2009:458:223-7.

32. Mattick JS. The genetic signatures of noncoding RNAs. PLoS Genet. 2009;5:e1000459.

33. Katayama S, Tomaru Y, Kasukawa T, Waki K, Nakanishi M, Nakamura M, et al. Antisense transcription in the mammalian transcriptome. Science. 2005;309:1564-6.

34. Rinn JL, Kertesz M, Wang JK, Squazzo SL, Xu X, Brugmann SA, et al. Functional demarcation of active and silent chromatin domains in human HOX loci by noncoding RNAs. Cell. 2007;129:1311-23.

35. Pauly JR, Sparks JA, Hauser KF, Pauly TH. In utero nicotine exposure causes persistent, gender-dependant changes in locomotor activity and sensitivity to nicotine in C57BI/6 mice. Int J Dev Neurosci. 2004;22:329-37.

36. Kumar R, Pratt JA, Stolerman IP. Characteristics of conditioned taste aversion produced by nicotine in rats. Br J Pharmacol. 1983;79:245-53.

37. Iwamoto ET, Williamson EC. Nicotine-induced taste aversion: characterization and preexposure effects in rats. Pharmacol Biochem Behav. 1984;21:527-32.

38. Gamber KM, Huo L, Ha S, Hairston JE, Greeley S, Bjorbaek C. Over-expression of leptin receptors in hypothalamic POMC neurons increases susceptibility to diet-induced obesity. PLoS One. 2012;7:e30485.

39. Paxinos G, Franklin KBJ. The mouse brain in stereotaxic coordinates. 2nd ed. Amsterdam, Boston: Elsevier Academic Press; 2004.

40. Cowley MA, Smart JL, Rubinstein M, Cerdan MG, Diano S, Horvath TL, et al, Leptin activates anorexigenic POMC neurons through a neural network in the arcuate nucleus. Nature. 2001;411:480-4.

41. Dobin A, Davis CA, Schlesinger F, Drenkow J, Zaleski C, Jha S, et al. STAR: ultrafast universal RNA-seq aligner. Bioinformatics. 2013;29:15-21.

42. Anders S, Pyl PT, Huber W. HTSeq-a Python framework to work with highthroughput sequencing data. Bioinformatics. 2015;31:166-9.

43. Robinson MD, McCarthy DJ, Smyth GK. edgeR: a Bioconductor package for differential expression analysis of digital gene expression data. Bioinformatics. 2010;26:139-40.

44. Anders $\mathrm{S}, \mathrm{Huber}$ W. Differential expression analysis for sequence count data. Genome Biol. 2010;11:R106.

45. Hardcastle TJ, Kelly KA. baySeq: empirical Bayesian methods for identifying differential expression in sequence count data. BMC Bioinforma. 2010;11:422

46. Mi H, Lazareva-Ulitsky B, Loo R, Kejariwal A, Vandergriff J, Rabkin S, et al. The PANTHER database of protein families, subfamilies, functions and pathways. Nucleic Acids Res. 2005;33:D284-8.

47. Florescu A, Ferrence R, Einarson T, Selby P, Soldin O, Koren G. Methods for quantification of exposure to cigarette smoking and environmental tobacco smoke: focus on developmental toxicology. Ther Drug Monit. 2009;31:14-30.

48. O'Connor RJ, Giovino GA, Kozlowski LT, Shiffman S, Hyland A, Bernert JT, et al. Changes in nicotine intake and cigarette use over time in two nationally representative cross-sectional samples of smokers. Am J Epidemiol. 2006;164:750-9.

49. Silva JP, von Meyenn F, Howell J, Thorens B, Wolfrum C, Stoffel M. Regulation of adaptive behaviour during fasting by hypothalamic Foxa2. Nature. 2009;462:646-50.

50. Frederich RC, Hamann A, Anderson S, Lollmann B, Lowell BB, Flier JS. Leptin levels reflect body lipid content in mice: evidence for diet-induced resistance to leptin action. Nat Med. 1995:1:1311-4.

51. Maffei M, Halaas J, Ravussin E, Pratley RE, Lee GH, Zhang Y, et al. Leptin levels in human and rodent: measurement of plasma leptin and ob RNA in obese and weight-reduced subjects. Nat Med. 1995;1:1155-61.

52. Bjorbaek C, Elmquist JK, Frantz JD, Shoelson SE, Flier JS. Identification of SOCS3 as a potential mediator of central leptin resistance. Mol Cell. 1998;1:619-25.

53. Kievit P, Howard JK, Badman MK, Balthasar N, Coppari R, Mori H, et al. Enhanced leptin sensitivity and improved glucose homeostasis in mice lacking suppressor of cytokine signaling-3 in POMC-expressing cells. Cell Metab. 2006;4:123-32.

54. Munzberg H, Flier JS, Bjorbaek C. Region-specific leptin resistance within the hypothalamus of diet-induced obese mice. Endocrinology. 2004;145:4880-9.

55. Ha S, Baver S, Huo L, Gata A, Hairston J, Huntoon N, et al. Somato-dendritic localization and signaling by leptin receptors in hypothalamic POMC and AgRP neurons. PLoS ONE. 2013;8:e77622.

56. Kim KS, Yoon YR, Lee HJ, Yoon S, Kim SY, Shin SW, et al. Enhanced hypothalamic leptin signaling in mice lacking dopamine D2 receptors. J Biol Chem. 2010;285:8905-17 
57. Maejima Y, Sakuma K, Santoso P, Gantulga D, Katsurada K, Ueta Y, et al. Oxytocinergic circuit from paraventricular and supraoptic nuclei to arcuate POMC neurons in hypothalamus. FEBS lett. 2014;588:4404-12.

58. Kiss J, Kocsis K, Csaki A, Gorcs TJ, Halasz B. Metabotropic glutamate receptor in $\mathrm{GHRH}$ and beta-endorphin neurones of the hypothalamic arcuate nucleus. Neuroreport. 1997:8:3703-7.

59. Pampillo M, Scimonelli T, Duvilanski BH, Celis ME, Seilicovich A, Lasaga M. The activation of metabotropic glutamate receptors differentially affects GABA and alpha-melanocyte stimulating hormone release from the hypothalamus and the posterior pituitary of male rats. Neurosci lett. 2002;327:95-8.

60. Masaki T, Chiba S, Yasuda T, Noguchi H, Kakuma T, Watanabe T, et al. Involvement of hypothalamic histamine $\mathrm{H} 1$ receptor in the regulation of feeding rhythm and obesity. Diabetes. 2004;53:2250-60.

61. Berglund ED, Liu C, Sohn JW, Liu T, Kim MH, Lee CE, et al. Serotonin $2 \mathrm{C}$ receptors in pro-opiomelanocortin neurons regulate energy and glucose homeostasis. J Clin Investig. 2013;123:5061-70.

62. Ito Y, Banno R, Shibata M, Adachi K, Hagimoto S, Hagiwara D, et al. GABA type $B$ receptor signaling in proopiomelanocortin neurons protects against obesity, insulin resistance, and hypothalamic inflammation in male mice on a high-fat diet. J Neurosci. 2013;33:17166-73.

63. Dicken MS, Tooker RE, Hentges ST. Regulation of GABA and glutamate release from proopiomelanocortin neuron terminals in intact hypothalamic networks. J Neurosci. 2012;32:4042-8.

64. Li SJ, Scanlon MN, Jarai Z, Varga K, Gantenberg NS, Lazar-Wesley E, et al. alpha-2-Adrenergic activation of proopiomelanocortin-containing neurons in the arcuate nucleus causes opioid-mediated hypotension and bradycardia. Neuroendocrinology. 1996;63:275-83.

65. Yamada M, Miyakawa T, Duttaroy A, Yamanaka A, Moriguchi T, Makita R, et al. Mice lacking the M3 muscarinic acetylcholine receptor are hypophagic and lean. Nature. 2001;410:207-12.

66. Kim TK, Hemberg M, Gray JM, Costa AM, Bear DM, Wu J, et al. Widespread transcription at neuronal activity-regulated enhancers. Nature. 2010;465:182-7.

67. Lam MT, Li W, Rosenfeld MG, Glass CK. Enhancer RNAs and regulated transcriptional programs. Trends Biochem Sci. 2014;39:170-82.

68. Visel A, Minovitsky S, Dubchak I, Pennacchio LA. VISTA Enhancer Browser-a database of tissue-specific human enhancers. Nucleic Acids Res. 2007:35:D88-92.

69. Heath CJ, Horst NK, Picciotto MR. Oral nicotine consumption does not affect maternal care or early development in mice but results in modest hyperactivity in adolescence. Physiol Behav. 2010;101:764-9.

70. Berglund ED, Vianna CR, Donato Jr J, Kim MH, Chuang JC, Lee CE, et al. Direct leptin action on POMC neurons regulates glucose homeostasis and hepatic insulin sensitivity in mice. J Clin Investig. 2012;122:1000-9.

71. Burke LK, Doslikova B, D'Agostino G, Greenwald-Yarnell M, Georgescu T, Chianese $R$, et al. Sex difference in physical activity, energy expenditure and obesity driven by a subpopulation of hypothalamic POMC neurons. Mol Metab. 2016:5:245-52.

72. Bruin JE, Kellenberger LD, Gerstein HC, Morrison KM, Holloway AC. Fetal and neonatal nicotine exposure and postnatal glucose homeostasis: identifying critical windows of exposure. J Endocrinol. 2007;194:171-8.

73. Shimada M, Nakamura T. Time of neuron origin in mouse hypothalamic nuclei. Exp Neurol. 1973;41:163-73.

74. Bouret SG, Draper SJ, Simerly RB. Formation of projection pathways from the arcuate nucleus of the hypothalamus to hypothalamic regions implicated in the neural control of feeding behavior in mice. J Neurosci. 2004;24:2797-805.

75. Nilsson I, Johansen JE, Schalling M, Hokfelt T, Fetissov SO. Maturation of the hypothalamic arcuate agouti-related protein system during postnatal development in the mouse. Brain Res Dev Brain Res. 2005;155:147-54.

76. de Wit J, Hong W, Luo L, Ghosh A. Role of leucine-rich repeat proteins in the development and function of neural circuits. Annu Rev Cell Dev Biol. 2011;27:697-729.

77. Hentges ST, Nishiyama M, Overstreet LS, Stenzel-Poore M, Williams JT, Low MJ. GABA release from proopiomelanocortin neurons. J Neurosci. 2004; $24: 1578-83$.

78. Hentges ST, Otero-Corchon V, Pennock RL, King CM, Low MJ. Proopiomelanocortin expression in both GABA and glutamate neurons. J Neurosci. 2009;29:13684-90.

79. Rohm B, Ottemeyer A, Lohrum M, Puschel AW. Plexin/neuropilin complexes mediate repulsion by the axonal guidance signal semaphorin 3A. Mech Dev. 2000;93:95-104.
80. Deiner MS, Sretavan DW. Altered midline axon pathways and ectopic neurons in the developing hypothalamus of netrin-1- and DCC-deficient mice. J Neurosci. 1999;19:9900-12.

81. Giacobini P, Messina A, Morello F, Ferraris N, Corso S, Penachioni J, et al Semaphorin $4 \mathrm{D}$ regulates gonadotropin hormone-releasing hormone-1 neuronal migration through PlexinB1-Met complex. J Cell Biol. 2008;183:555-66.

82. Cariboni A, Davidson K, Rakic S, Maggi R, Parnavelas JG, Ruhrberg C. Defective gonadotropin-releasing hormone neuron migration in mice lacking SEMA3A signalling through NRP1 and NRP2: implications for the aetiology of hypogonadotropic hypogonadism. Hum Mol Genet. 2011:20:336-44.

83. Xu C, Fan CM. Expression of Robo/Slit and Semaphorin/Plexin/Neuropilin family members in the developing hypothalamic paraventricular and supraoptic nuclei. Gene Expr Patterns. 2008;8:502-7.

84. Wang $X$, Kopinke D, Lin J, McPherson AD, Duncan RN, Otsuna H, et al. Wnt signaling regulates postembryonic hypothalamic progenitor differentiation. Dev Cell. 2012;23:624-36.

85. Parkash J, Cimino I, Ferraris N, Casoni F, Wray S, Cappy H, et al. Suppression of beta1-integrin in gonadotropin-releasing hormone cells disrupts migration and axonal extension resulting in severe reproductive alterations. J Neurosci. 2012;32:16992-7002.

86. Takeichi M. The cadherin superfamily in neuronal connections and interactions. Nat Rev Neurosci. 2007:8:11-20.

87. Su H, Marcheva B, Meng S, Liang FA, Kohsaka A, Kobayashi Y, et al. Gammaprotocadherins regulate the functional integrity of hypothalamic feeding circuitry in mice. Dev Biol. 2010;339:38-50.

88. Aujla PK, Naratadam GT, Xu L, Raetzman LT. Notch/Rbpjkappa signaling regulates progenitor maintenance and differentiation of hypothalamic arcuate neurons. Development. 2013;140:3511-21.

89. Yan J, Zhang H, Yin Y, Li J, Tang Y, Purkayastha S, et al. Obesity- and aginginduced excess of central transforming growth factor-beta potentiates diabetic development via an RNA stress response. Nat Med. 2014;20:1001-8.

90. de la Monte SM, Wands JR. Alzheimer's disease is type 3 diabetes-evidence reviewed. J Diabetes Sci Technol. 2008;2:1101-13.

91. Bellefroid EJ, Kobbe A, Gruss P, Pieler T, Gurdon JB, Papalopulu N. Xiro3 encodes a Xenopus homolog of the Drosophila Iroquois genes and functions in neural specification. EMBO J. 1998;17:191-203.

92. Sakakibara S, Imai T, Hamaguchi K, Okabe M, Aruga J, Nakajima K, et al. Mouse-Musashi-1, a neural RNA-binding protein highly enriched in the mammalian CNS stem cell. Dev Biol. 1996;176:230-42.

93. Sakakibara S, Okano $\mathrm{H}$. Expression of neural RNA-binding proteins in the postnatal CNS: implications of their roles in neuronal and glial cell development. J Neurosci. 1997;17:8300-12.

94. Nakanishi H, Obaishi H, Satoh A, Wada M, Mandai K, Satoh K, et al. Neurabin: a novel neural tissue-specific actin filament-binding protein involved in neurite formation. J Cell Biol. 1997;139:951-61.

\section{Submit your next manuscript to BioMed Central and we will help you at every step:}

- We accept pre-submission inquiries

- Our selector tool helps you to find the most relevant journal

- We provide round the clock customer support

- Convenient online submission

- Thorough peer review

- Inclusion in PubMed and all major indexing services

- Maximum visibility for your research

Submit your manuscript at www.biomedcentral.com/submit 